\title{
Bounding the Price Equivalent of Migration Barriers
}

Michael A. Clemens, Claudio Montenegro and

Lant Pritchett

CID Working Paper No. 316

March 2016

(c) Copyright 2016 Clemens, Michael; Montenegro,

Claudio; Pritchett, Lant; and the President and Fellows of

Harvard College

\section{Working Papers Center for International Development at Harvard University}




\title{
Bounding the Price Equivalent of Migration Barriers
}

\author{
Michael A. Clemens* \\ Center for Global \\ Development and IZA
}

\author{
Claudio Montenegro \\ World Bank and \\ University of Chile
}

\author{
Lant Pritchett \\ Harvard Kennedy \\ School and CGD
}

March 2016

\begin{abstract}
Large international differences in the price of labor can be sustained by differences between workers, or by natural and policy barriers to worker mobility. We use migrant selection theory and evidence to place lower bounds on the ad valorem equivalent of labor mobility barriers to the United States, with unique nationally-representative microdata on both U.S. immigrant workers and workers in their 42 home countries. The average price equivalent of migration barriers in this setting, for low-skill males, is greater than $\$ 13,700$ per worker per year. Natural and policy barriers may each create annual global losses of trillions of dollars.
\end{abstract}

\footnotetext{
${ }^{*}$ JEL Codes F22, J61, J71, O15. We are grateful to Indermit S. Gill and his team at the World Development Report of the World Bank who built and allowed use of the database. We thank Samuel Bazzi and Paolo Abarcar for excellent research assistance. We received helpful comments from Randall Akee, Christopher Blattman, Patricia Cortés, William Easterly, David Ellwood, Deon Filmer, Eric Gould, Rema Hanna, Eric Hanushek, Ricardo Hausmann, Chad Jones, Lawrence Katz, John Kennan, Asim Khwaja, Robert Lawrence, David Lindauer, David McKenzie, Dani Rodrik, Mark Rosenzweig, Justin Sandefur, T. N. Srinivasan, anonymous referees, and seminar participants at the AEA annual meetings, Yale University Dept. of Economics, Harvard Kennedy School, the Brookings Institution, the University of Maryland Dept. of Economics, the LACEA annual meetings, and the Center for Global Development. This work was partially supported by generous grants from the John D. and Catherine T. MacArthur Foundation, AusAID, and Good Ventures. The paper represents the views of the authors alone and not necessarily those of their employers or funders.
} 


\section{Introduction}

Economists often study the costs of frictions in international commerce by estimating their ad valorem equivalent. Such estimates are made for frictions that include trade quotas (Anderson and van Wincoop 2004; Irarrázabal et al. 2015), transportation costs (Finger and Yeats 1976; Hummels 2007), and capital controls (Edwards et al. 1999). But there are no systematic estimates of the price equivalent of barriers to the international movement of labor. Both the simple "Harberger triangle" intuition that the welfare losses rise with the square of the price distortion (Hines 1999) and calibrated models of the world economy suggest that if the price equivalent of migration barriers is high, the annual global costs are trillions of dollars. ${ }^{1}$

We use a unique collection of data sets on individuals' wages from 42 developing countries and the United States to place lower bounds on the price equivalent of barriers to labor mobility into the U.S. market. We estimate the real (Purchasing Power Parity) wage gaps between immigrants in the United States and their observably-equivalent national counterparts in the 42 home labor markets. We then use theory and evidence on migrant self-selection to bound the real wage gap for fully equivalent workers - adjusted for both observable and unobservable characteristics. Because it does not arise from portable individual traits, this wage gap has been called the 'place premium' (Clemens et al. 2009). We then use these bounds on the place premium to discuss what fraction of this price wedge might plausibly be attributed to natural barriers and what fraction to policy barriers.

Our focus is on prime-age, low-skill males educated abroad (35-39 years old, 9-12 years of education acquired in the home country), though we present estimates for other demographic categories as well. We calculate lower bounds on the ratio of real wages in the U.S. to real wages of an identical worker in each home country. This lower bound varies greatly across countries, from a high of 16.4 for Yemen to a low of 1.7 for Morocco. Weighted by the working-age (15-49) population of the home countries, the average lower bound on this wage ratio is 5.65. For the median country the lower bound is 3.95 , and for the $80^{\text {th }}$

\footnotetext{
${ }^{1}$ Surveyed by Clemens (2011), and recently investigated by Benhabib and Jovanovic (2012); Kennan (2013); di Giovanni et al. (2015); Bradford (2015).
} 
percentile country the lower bound is 6.14. The working-age population weighted average of the lower bound on the absolute wage gain is $\operatorname{PPP} \$ 13,710 /$ year across 1.5 billion working-age people from the 42 countries. The lower bound absolute gain for workers from the median country is $\operatorname{PPP} \$ 13,600$, and for the $80^{\text {th }}$ percentile country it is $\operatorname{PPP} \$ 15,600$.

We cannot separately estimate for each country the relative contributions of natural and policy barriers. That said, we note that spatially integrated labor markets in the absence of policy barriers rarely sustain real wage ratios above 1.5 - even in the presence of important cultural and geographic barriers. This suggests a plausible prior that policy barriers to labor mobility account for at least as much of the observed gap in wages of fully equivalent workers than do natural barriers to movement, such as psychic costs or transportation costs.

This work contributes the first country-specific bounds on the price equivalent of migration barriers using data on nationally-representative samples of individual workers from the same country working on both sides of the border. Ashenfelter (2012) measures large real wage gaps between several countries within one low-skill occupation: fast-food workers. Multiple studies use microdata on migrants to find that country of residence is at least as important a determinant of worker productivity as inherent characteristics, but do not estimate international labor-price wedges separately by country (Hendricks 2002; Rosenzweig 2010; Milanovic 2015; Hendricks and Schoellman 2016).

\section{Wage ratios for observably equivalent workers}

The calculations we make are best understood as analogous to ad valorem measures of trade barriers. Foreign sugar in the United States, for example, faces both natural barriers (including transportation costs) and policy barriers (including quotas and tariffs). Each potential sugar-exporting country is allocated a share (which can be zero) of an overall quota of sugar which is allowed to enter the US at low tariff rates - the "tariff reduced quota" or TRQ - after which they pay a high tariff. The tariff equivalent of these barriers 
for each country $i$ is

$$
\frac{p^{\mathrm{US}, i}}{p^{i}}-1=\tau\left(q^{i}, Q^{\text {total }}\right),
$$

where $p^{\mathrm{US}, i}$ is the domestic U.S. price of sugar from the $i^{\text {th }}$ country, and $p^{i}$ is the supply price of sugar from country $i$ for sale in the U.S. market. When measured as the overseas ('free on board') price, $p^{i}$ measures the forgone revenue that could be had from selling in that overseas market. In this case $\tau$ is an ad valorem measure of all barriers to trade faced by a potential sugar-importer, both natural barriers and policy barriers. When $p^{i}$ is measured as the landed ('cost, insurance, freight') price and inclusive of any incremental transactions costs of getting the sugar to the U.S. market the $\tau$ is an ad valorem measure of the quotas. This tariff equivalent depends on the price of the good from the $i^{\text {th }}$ country in the U.S. market because the goods might not be perfect substitutes or might differ in quality. Even if sugar from different countries is a perfect substitute and sugar has a single price in the U.S., there are still tariff equivalents of the country-specific and overall quotas.

We seek to place bounds on similar price ratios for labor, as ad valorem measures of barriers to labor mobility. As for trade, this requires comparing likes with likes. The large and obvious international differences in the price of labor could arise from observable differences in the inherent productivity of individual workers, unobservable differences in that inherent productivity, or spatial differences in worker productivity linked to their surroundings. Location-based differences in worker productivity can be sustained by 'natural' barriers that include workers' transportation costs. They can also be sustained by policy barriers that include binding quotas on migration. ${ }^{2}$ As in equation (1), such price differences can be expressed as wage ratios.

\subsection{Defining the wage ratios}

Figure 1 schematically summarizes the wage ratios we calculate. $R_{u}$ is the unconditional ratio of migrants' wages in the United States to wages in the home country, without ad-

\footnotetext{
${ }^{2}$ For example, for each person granted a U.S. Diversity Visa in 2015, there were 288 qualified applicants for the visa. According to the U.S. State Department, there were 14,397,781 qualified applicants including derivatives (family members who count against the quota of 50,000 visas).
} 
justment for observable or unobservable differences between average migrants and average non-migrants. $R_{c}$ is the ratio conditional on observable inherent differences like age and education. Finally, $R$ accounts for all inherent differences, both observable and unobservable. That is, ratio $R$ measures the real wage gain that the same person could expect in the U.S. relative to the home country.

Formally, suppose that a worker born and educated in a foreign country would earn $w_{0}$ in that home country and earn $w_{\mathrm{US}}$ in the United States, and that $w_{0}$ and $w_{\mathrm{US}}$ are are determined by:

$$
\begin{aligned}
& \ln w_{0}=\left(\mu_{0}+\gamma_{0} s\right)+\widetilde{\gamma}_{0} \widetilde{s} \equiv \mu_{0}^{\prime}(s)+\widetilde{\gamma}_{0} \widetilde{s} \\
& \ln w_{\mathrm{US}}=\left(\mu_{\mathrm{US}}+\gamma_{\mathrm{US}} s\right)+\widetilde{\gamma}_{\mathrm{US}} \widetilde{s} \equiv \mu_{\mathrm{US}}^{\prime}(s)+\widetilde{\gamma}_{\mathrm{US}} \widetilde{s},
\end{aligned}
$$

where $s \geqslant 0$ is observed skill, which has return $\gamma_{0}$ abroad and $\gamma_{\mathrm{US}}$ in the United States; $\widetilde{s} \sim N(0, \sigma)$ is unobserved skill, which has return $\widetilde{\gamma}_{0}$ abroad and $\widetilde{\gamma}_{\mathrm{US}}$ in the United States. Fundamental differences in worker productivity between the two countries are captured by $\mu_{\mathrm{US}}$ and $\mu_{0}$.

The three wage ratios of interest can then be defined as

$$
\begin{aligned}
\ln R_{u} & \equiv \mu_{\mathrm{US}}-\mu_{0}+\left(\gamma_{\mathrm{US}} E_{\mathrm{US}}[s]-\gamma_{0} E_{0}[s]\right)+\left(\widetilde{\gamma}_{\mathrm{US}} E_{\mathrm{US}}[\widetilde{s}]-\widetilde{\gamma}_{0} E_{0}[\widetilde{s}]\right) \\
\ln R_{c}(s) & \equiv \mu_{\mathrm{US}}-\mu_{0}+\left(\gamma_{\mathrm{US}}-\gamma_{0}\right) E_{\mathrm{US}}[s]+\left(\widetilde{\gamma}_{\mathrm{US}} E_{\mathrm{US}}[\widetilde{s}]-\widetilde{\gamma}_{0} E_{0}[\widetilde{s}]\right) \\
\ln R(s, \widetilde{s}) & \equiv \mu_{\mathrm{US}}-\mu_{0}+\quad\left(\gamma_{\mathrm{US}}-\gamma_{0}\right) E_{\mathrm{US}}[s]+\left(\widetilde{\gamma}_{\mathrm{US}}-\widetilde{\gamma}_{0}\right) E_{\mathrm{US}}[\widetilde{s}] .
\end{aligned}
$$

where $E_{0}$ and $E_{\mathrm{US}}$ denote expectations - across residents of the home country and residents of the United States, respectively - for people born in a given home country.

The ratio $R$ is the 'place premium' of Clemens et al. (2009), the real wage premium that a worker can earn by working in the United States rather than their home country. It is a retrospective measure of the wage gains of current migrants. ${ }^{3}$ Provided marginal

\footnotetext{
${ }^{3}$ All of these ratios are the average treatment effect on the treated (ATET) as defined by Cameron and Trivedi (2005, p. 868): they are measures, with different biases, of the effect of migration on people who have migrated - not the average treatment effect (ATE), which in this case would represent the effect of
} 
new migrants earn the same wage, in expectation, as the average previous migrant the place premium also approximates the wage gains for prospective marginal new migrants. Borjas and Friedberg (2009) find that newly-arrived US immigrants in the year 2000 earned roughly as much, relative to natives, as observably equivalent newly-arrived immigrants earned twenty years earlier.

The ratios $R_{u}, R_{c}$, and $R$ compactly summarize migrant selection on observed and unobserved wage determinants. $R_{u} / R_{c}>1$ if and only if there is positive selection of migrants on observables, since $\ln \left(R / R_{c}\right)=\gamma_{0}\left(E_{\mathrm{US}}[s]-E_{0}[s]\right)>0 \Leftrightarrow E_{\mathrm{US}}[s]>E_{0}[s]$. Likewise, $R_{c} / R>1$ if and only if there is positive selection of migrants on unobservables, since $\ln \left(R_{c} / R\right)=\widetilde{\gamma}_{0}\left(E_{\mathrm{US}}[\widetilde{s}]-E_{0}[\widetilde{s}]\right)>0 \Leftrightarrow E_{\mathrm{US}}[\widetilde{s}]>E_{0}[\widetilde{s}]$.

To begin to estimate these ratios, for each country of birth we run a separate regression for all workers born there:

$$
\ln w=\alpha+\beta I_{\mathrm{US}}+\boldsymbol{I}_{\text {edu }}^{\prime}\left(\boldsymbol{\eta}_{\text {edu }}+\boldsymbol{\zeta}_{\text {edu }} I_{\mathrm{US}}\right)+\boldsymbol{I}_{\text {age }}^{\prime}\left(\boldsymbol{\eta}_{\text {age }}+\boldsymbol{\zeta}_{\text {age }} I_{\mathrm{US}}\right)+I_{\mathrm{fem}}\left(\eta_{\mathrm{fem}}+\zeta_{\mathrm{fem}} I_{\mathrm{US}}\right)+\varepsilon
$$

where $w$ is the monthly wage in U.S. dollars, and $I_{\mathrm{US}}$ is equal to one if the person lives in the United States, zero otherwise. $\boldsymbol{I}_{\text {edu }}$ and $\boldsymbol{I}_{\text {age }}$ are vectors of indicator variables for different groupings of years-of-education and quinquennial age, and $I_{\text {fem }}$ is an indicator for female. ${ }^{4}$ To be estimated are the parameters $\alpha, \beta, \eta_{\mathrm{fem}}$, and $\zeta_{\mathrm{fem}}$, and the parameter vectors $\boldsymbol{\eta}_{\text {edu }}, \boldsymbol{\zeta}_{\text {edu }}, \boldsymbol{\eta}_{\text {age }}, \boldsymbol{\zeta}_{\text {age }}$, while $\varepsilon$ is an error term. This specification allows all observable traits to have different returns in the two countries. Using indicator variables for different values of education and age reduces the sensitivity of results to assumptions about functional form (Heckman et al. 2006).

The key parameters are $\beta$ and the vectors $\zeta$. When the regression is run without any covariates other than $I_{\mathrm{US}}, \hat{\beta}=\ln \hat{R}_{u}$ characterizes the simple wage ratio without accounting for differences between migrants and non-migrants. When it is run with the full set

migration on a randomly-selected person from the origin country.

${ }^{4}$ The six education categories are 1) no schooling, 2) 1-4 years of schooling, 3) 5-8 years, 4) 9-12 years, 5) 13-16 years, and 6) 17-28 years. The ten age categories are 1) 15-19, 2) 20-24, 3) 25-29, 4) 30-34, 5) 35-39, 6) 40-44, 7) 45-49, 8) 50-54, 9) 55-59, 10) 60-65 (intentionally includes 65). The regressions also include dummy variables for the periodicity of wage reported (daily, weekly, etc.), suppressed here for clarity, with monthly as the base group. 
of covariates in $(7), \hat{\beta}+\hat{\zeta}_{\text {edu }}^{9-12}+\hat{\zeta}_{\text {age }}^{35-39}=\ln \hat{R}_{c}$ characterizes the wage ratio for observably equivalent migrants and non-migrants: 35-39 year-old males with 9-12 years of education.

\subsection{Results}

We use a unique standardized collection of individual level data sets on wage-earners compiled by the World Bank, combined with the US Census Public Use Microdata Sample (PUMS) five percent file. ${ }^{5}$ The unified database describes 2,015,411 individual wageearners, age 15 to 65 , residing in 43 countries close to the year 2000. This comprises 891,158 individuals residing in 42 developing countries, 623,934 individuals born in those same 42 developing countries but residing in the US, and 500,319 individuals born in the US and residing in the US. Wages are measured in 1999 US dollars at Purchasing Power Parity (PPP).

Table 1 presents estimates of $R_{u}$ and $R_{c}$ where wages are measured in Purchasing Power Parity (PPP) U.S. dollars. The first column shows $\hat{\beta}$ without any controls for education, age, and sex; the second column shows $\hat{\beta}+\hat{\zeta}_{\text {edu }}^{9-12}+\hat{\zeta}_{\text {age }}^{35-39}$ with controls included. ${ }^{6}$ The third column repeats the regressions with controls, but drops all U.S.-resident workers who were less than 20 years old when they arrived in the country. This eliminates most workers who received U.S. education, since domestic education and foreign education can have markedly different returns (Chiswick 1978; Friedberg 2000). These last results are converted to the wage ratio $\hat{R}_{c}$ for the final column, and countries are sorted in decreasing values of this ratio.

\footnotetext{
${ }^{5}$ Details of the database and all sources are given in the Appendix. The U.S. microdata are described by U.S. Census Bureau (2008). The developing-country database is described by Montenegro and Hirn (2009).

${ }^{6}$ The difference between the first and second column of results matches several results in the literature. The fact that the wage ratio falls for most countries when basic observable controls are added implies positive selection of migrants on observable determinants of earnings. The fact that migrants from most countries are positively selected on observed education levels found by studies that compare the education levels of emigrants and non-emigrants across numerous countries (Feliciano 2005; Brücker and Defoort 2009). The small change in the coefficient for Mexico when controls are added is compatible with previous findings of approximately neutral selection on observables for Mexico-U.S. migrants (Chiquiar and Hanson 2005; Orrenius and Zavodny 2005), and the fact that the coefficient does fall slightly is compatible with findings of modest negative selection on basic observables (Fernández-Huertas 2011; Kaestner and Malamud 2014; Ambrosini et al. 2015). The ratio likewise rises slightly between columns 1 and 2 for Nicaragua, in agreement with Barham and Boucher's (1998) finding of negative selection on observables for that country.
} 
The estimated wage ratios are very large. For the working-age population weighted average country of birth, $R_{c}=6.84$ while for the median country of birth, $R_{c}=4.5$ (five of the six largest countries in our sample (India, Indonesia, Bangladesh, Pakistan, Nigeria) have estimates above the median). These ratios represent the difference in purchasing poweradjusted wages between immigrants to the U.S. who received their education in the home country and observably equivalent workers in their country of origin - 35-39 year-old male workers with 9-12 years of education who were born and educated in that home country.

The ratios are quite precisely estimated due to the large and nationally-representative samples used for all countries. For the ratios $R_{c}$, the $t$-statistic is above 10 in 38 out of 42 countries. Standard errors on $\hat{R}_{c}$ are bootstrapped with 500 draws to avoid the retransformation problem, as recommended by Manning (1998).

These PPP-dollar estimates capture differences in worker real income to the extent that wages are spent at U.S. prices. Large fractions of some migrants' earnings are remitted to the home country and spent there. ${ }^{7}$ For such earnings, the relevant wage differences should be calculated at official exchange rates. Table 2 carries out this exercise; many of the ratios are much larger. At official exchange rates, $R_{c}$ takes the value 18.9 in the average country of birth, and 13.9 in the median country of birth.

The large magnitude of these estimates is unlikely to arise from reporting bias of posttax income. Research comparing multiple sources of income data at the individual level suggest that self-reported income is an unbiased estimator of true income, both in rich countries (Bound et al. 1991) and poor countries (Akee 2011). Wage data for the U.S. reflect total earnings from all jobs, whereas wage data for the 42 developing countries in our

\footnotetext{
${ }^{7}$ Amuedo-Dorantes et al. (2005, Table 1A) find that Mexican migrant household heads in the United states remit $28 \%$ of monthly income to Mexico, a figure that includes non-remitters and does not include repatriated savings. Semyonov and Gorodzeisky (2005, Table 1) find that male overseas Filipino workers remit $60 \%$ of monthly income to the Philippines, while females remit $45 \%$. Migrants, especially temporary workers, should optimally have very high savings rates. A simple model of inter-temporal consumption smoothing would suggest that if a worker had access to a much higher wage rate for an explicitly temporary period they should optimally smooth these windfall gains over his or her lifetime. Alternatively, temporary migration is often modeled as driven by "target savers" who accumulate savings for a specific purpose (e.g. a house, business, car, wedding/marriage), consumption that, again, would occur in their country of origin not in the U.S. Much, perhaps most consumption of the US earnings of temporary migrants would be in their own country, not the US (see for example Dustmann and Mestres 2010).
} 
sample reflect wages from the respondent's principal occupation, but this closely reflects total wage earnings for the vast majority of workers. Wage data for the U.S. and most of the developing countries reflect gross earnings before taxes, but for a handful of countries it may be that the responses reflect after-tax wages. ${ }^{8}$ Any bias thereby introduced will be small, as formal-sector income taxes are on the order of $5 \%$ in most developing countries (Easterly and Rebelo 1993). Reported wages in the U.S. census do not include non-wage benefits, which are likely to be a larger fraction of total compensation in the U.S. than in many of the countries examined here; this would exert a small downward bias on the ratios in Tables 1 and 2.

\section{Bounding selection bias}

The principal objection to the use of $R_{c}$ to estimate the wage of equivalent labor in two different labor markets is that migrants are self-selected. The counterfactual wages of the workers now in the U.S. could have been different, if they had remained at home, than the wages of observably equivalent workers at home due to unobserved differences. For U.S. migrants negatively selected on unobserved determinants of earnings, the estimates $R_{c}$ constitute a lower bound on the wage ratio for fully equivalent workers $R$. This is suggested by existing evidence for Mexico (Fernández-Huertas 2011; Ambrosini and Peri 2012).

On the other hand, $R_{c}$ can overstate $R$ under positive selection on unobservable determinants of wages. We focus on low-skill workers, following Ashenfelter (2012), for whom such selection might be attenuated by the fact that they tend to work in occupations without plausibly high returns to unobserved skill—such as janitorial services. ${ }^{9}$ A reasonable prior is that the incentive for janitors to move to the United States is not greatly influenced by

\footnotetext{
${ }^{8}$ In a small number of the countries (such as Yemen) the survey explicitly requests after-tax earnings, and in a few of the others (such as Chile) custom may dictate that formal sector 'wages' refer to after-tax earnings unless otherwise specified. The text of the wage question from each survey is in the Appendix.

${ }^{9}$ We focus on workers with 9-12 years of education. In the United States, the five most common occupations for workers with less than high-school education are truck and other drivers, janitors and building cleaners, food preparation workers, construction laborers, and housekeeping cleaners. For those with high-school education only, the same list also includes drivers and janitors, but furthermore includes laborers and other movers, secretaries, and workers in retail sales (Carnevale et al. 2011, p. 13-14).
} 
outsize labor-market returns for the best janitors. Our focus on U.S. immigration may also attenuate selection bias relative to other settings, since the large majority of U.S. immigrants acquire permanent residence through family ties with little policy selection regarding their earning potential. ${ }^{10}$

This said, nonzero positive selection on unobservables is nevertheless possible and is predicted by theory under certain conditions. Using the rich microdata at our disposal we take three approaches to estimating informative bounds on $R$ that allow for positive selection on unobservables. The first is to use the coefficent stability estimates of lower bounds of treatment effects, comparing the results to existing empirical estimates of selection on unobservables. We also pursue two further and complementary approaches to characterizing the direction and magnitude of selection bias in this setting. We derive tests for bias due to positive selection using the most influential basic theories of selection. One of these approaches tests predictions about Roy (1951) positive self-selection; the other approach tests predictions about positive selection arising from capital constraints.

\subsection{Lower bounds from coefficient stability}

The first approach is to estimate the degree of bias that would arise from different degrees of selection on unobservables, and compares this to selection estimates from the literature. Altonji et al. (2005) propose a method for bounding treatment effects under unobserved self-selection into treatment. They suggest that in many empirical settings the degree of selection on unobservables can be bounded from above by the degree of selection on observables. In rough terms, this is because if the included (observed) covariates were chosen at random from the set of possible (observed or unobserved) covariates, then the degree of selection on observables would equal the degree of selection on unobservables. Researchers typically do not choose included covariates at random but specifically to reduce bias guided by theory, thus degree of selection explained by deliberately-chosen covariates must exceed the degree explained by omitted covariates. This suggests an avenue for bounding the degree of migrant selection on unobserved determinants of earnings, given

\footnotetext{
${ }^{10}$ Only $16 \%$ of immigrants acquire U.S. permanent residence on the basis of employment. Almost all the rest acquire permanent residence through family ties (63\%), refugee/asylum (15\%), and the Diversity Visa lottery (4\%) (Orrenius and Zavodny 2010, p. 22).
} 
that variables like education, age, and gender are chosen not at random but specifically to reduce selection bias: all are known to be first-order determinants of both earnings and migration.

Recently, Oster (2015) observes that this method may not be sufficiently conservative and extends the method. Following Imbens (2003), she shows that plausible bounds on selection must take account of the fraction of covariance in outcomes and treatment that is explained by observables. In other words, researchers must not only assert that they chose observables to reduce selection bias, but show that those observables do have the explanatory power to reduce selection bias. Oster derives the consistent estimator for a treatment effect $\beta$,

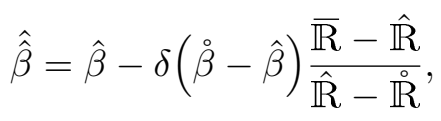

where $\hat{\beta}$ and $\hat{\mathbb{R}}$ are the estimated treatment effect and the coefficient of determination $\left(R^{2}\right)$ from the regression including observed controls; $\stackrel{\circ}{\beta}$ and $\mathbb{R}$ are the estimate and the coefficient of determination without any controls; $\delta$ is the ratio of the degree of selection on unobservables to the degree of selection on observables; and $\overline{\mathbb{R}} \equiv \Pi \hat{\mathbb{R}}$ is the coefficient of determination from a hypothetical regression that includes all important observed and unobserved controls $(\Pi>1)$. With conservative choices for $\delta$ and $\Pi$, (8) can bound the true treatment effect. ${ }^{11}$ Alternatively, setting $\hat{\hat{\beta}}=0$ in (8) and solving for $\delta$ allows estimation of how large selection on unobservables must be, relative to selection on observables, for the true treatment effect to be zero. The method has found wide application (e.g. Mian and Sufi 2014; Collins and Wanamaker 2014; González and Miguel 2015).

Oster proposes a standard for reporting results of $\delta=1$ and $\Pi=1.3$, the level of stability typically demonstrated by studies in the literature where treatment is randomized. She shows that this standard is stringent: the central results of 30 of 65 (46\%) of studies published in five leading economics journals fail to meet this standard. Under an even more stringent test at $\Pi=2,43$ of $65(66 \%)$ of the studies fail to reject a zero treatment effect.

\footnotetext{
${ }^{11}$ Intuitively, if the explanatory power of the observables is much less than the amount of variance left to explain $(\hat{\mathbb{R}}-\mathbb{R} \ll \overline{\mathbb{R}}-\hat{\mathbb{R}})$, changes in the treatment effect estimate upon inclusion of observables $(-\delta(\dot{\beta}-\hat{\beta}))$ become uninformative about the degree of selection on unobservables.
} 
We can apply these standards to compute a lower bound on $R$ for each country. Table 3 carries out this bounding exercise for the wage ratios at purchasing power parity, for a 35-39 year-old male with 9-12 years of education. The first column reproduces $\hat{R}_{c}$ from Table 1. The second column estimates lower bounds on $R$ using (8), under the robustness standard for quasi-random treatment assignment: $\Pi=1.3$ and $\delta=1$. All of these bounds remain above a treatment effect of zero $(R=1)$ and most remain very large. The lower bound on $R$ exceeds 5.0 in 17 countries and exceeds 3.0 in 29 out of 42 countries.

The third column adopts the even more conservative standard of $\Pi=2$. The lower bound on $R$ is still above 1.0 for 40 out of 42 countries, and above 3.0 for 22 countries. ${ }^{12}$

In column 4 we report the relative degree of selection on unobservables to observables $(\delta)$ that would be necessary in order for the estimated ratio $R_{c}$ to be consistent with $R=1$ ) using $\Pi=1.3$. The selection on unobservables would typically need to be an order of magnitude larger than selection on observables (median $\left.\delta\right|_{R=1}=12.2,80^{\text {th }}$ percentile $23.5)$ for $R$ to be unity given the observed $R_{c}$. Column 5 reports the ratio $R_{u} / R_{c}$, showing generally positive selection on observables, with a median of 1.17 . The median ratio of the estimates of the coefficient-stability lower bound on $R$ is 1.12 . The median ratio of the lower bounds on $R$ in the third column $(\Pi=2)$ to $R_{c}$ is 1.44 .

Is it plausible that selection on unobservables is an order of magnitude greater than selection on observables? Several studies of migrant self-selection have recently been done, in a variety of settings, that allow calculation of the relevant parameters. Table 4 presents all estimates of which we are aware. 11 of these use panel data to compare non-migrants with subsequent migrants prior to migration. These 11 results come from a variety of settings: origin areas both rich (Finland) and poor (Tonga); policy barriers both absent (Poland) and present (Mexico); distance both short (Lithuania) and long (Micronesia); time both contemporary (Israel) and historical (Norway). None of these settings records

\footnotetext{
${ }^{12}$ For two of the countries-Yemen and Cambodia - the procedure provides upper bounds on $R$ and suggests that the original $R_{c}$ is a lower bound on $R$. Note that this method does not yield a better or unbiased estimate of $R$ but a lower bound on $R$. The lower bound can be lower either because the center of the confidence interval falls or because the range of uncertainty rises. Changing the assumed $\Pi$ does not provide any intuitive reason to shift the actual estimate of $R$ (that is, there actually is more positive selection of migrants), just a reason to adjust the confidence-we cannot be positive the results are not tainted by positive selection.
} 
positive selection on unobservables with $\delta$ exceeding 0.89 . In six cases there is positive selection on unobserved determinants of earnings, but the highest $R_{c} / R$ ever recorded is 1.36. In three cases there is no appreciable selection on unobservables despite selection on observables, thus $\delta \approx 0$. In two of the cases there is negative selection on unobservables $\left(R_{c} / R<1\right)$, so that $R_{c}$ serves as a lower bound on $R$. Both are studies of Mexico-US migration; in one of these $\delta<1$ and in the other, $\delta$ reaches +2.25 . One study has used retrospectively-reported pre-migration wages for recent U.S. immigrants to estimate $\delta<\frac{1}{3}$ for a group of home countries comprising 36 of the 42 we study, and $\delta \approx 1$ in the rest. ${ }^{13}$ In all of these cases of positive selection on unobservables where it is possible to estimate $\delta$ given the published results, $\delta$ is approximately equal to or much less than 1.

These studies support the interpretation of column 2 of Table 3 as conservative lower bounds on $R$ (not as unbiased or consistent estimates of $R$ ). The working-age populationweighted average of the lower bounds on $R$ is 5.65. The lower bound for the median country (the Philippines) is 3.48 , and for the $80^{\text {th }}$ percentile country (India) is 5.93.

The final column of Table 3 shows the dollar-value difference in PPP annual wages implied by $\left.R\right|_{\delta=1, \Pi=1.3}$. These are best interpreted as lower bounds on the price equivalent for observably and unobservably equivalent low skill, male, prime-age workers between the home country and the United States.

\subsection{Testing predictions of Roy-model self-selection}

We can gain more insight into the plausibility of large positive selection on unobservables by testing necessary conditions implied by theory. Here we follow Hanson's (2006) nonstochastic extension of the Roy (1951)-Borjas (1991) model of migrant self-selection, and consider selection on unobservables within observed skill groups as in Ambrosini and Peri

\footnotetext{
${ }^{13}$ Hendricks and Schoellman (2016) report relative self-selection on observable and overall wage determinants, using retrospectively recalled pre-migration earnings, for recently-arrived U.S. immigrants from five broad groups of countries. They do not report exact estimates of $\delta$ or estimates by country. But they do report graphical decomposition of selection that allows bounds on $\delta$ for recent U.S. immigrants. For these immigrants overall, the vast majority of self-selection on earnings determinants arises from selection on observables $(\delta \ll 1)$. For workers from the group of countries with greater than 1/16 of U.S. PPP GDP per capita (including 36 of the 42 countries studied here), they find $\delta<\frac{1}{3}$. For the very poorest countries (the other eight of the 42 countries studied here), they find $\delta \approx 1$.
} 
(2012, p. 131). Suppose a worker with observed skill $s$ will migrate if U.S. wages exceed the forgone foreign wage plus migration costs: $\ln w_{\mathrm{US}}-\ln \left(w_{0}+C\right)>0$. Expressing migration cost in time-equivalent form $\left(\pi \equiv C / w_{0}\right)$, then by (2) and (3) workers migrate if unobserved skill satisfies

$$
\widetilde{s}>\frac{\pi-\left(\mu_{\mathrm{US}}^{\prime}(s)-\mu_{0}^{\prime}(s)\right)}{\widetilde{\gamma}_{\mathrm{US}}-\widetilde{\gamma}_{0}} \equiv \underline{s}(s) .
$$

This standard result implies that migrants will exhibit positive selection on unobservables if the return to observables at the destination exceeds the return at the origin $\left(\widetilde{\gamma}_{\mathrm{US}}>\widetilde{\gamma}_{0}\right)$. But because we have data from numerous countries, we can derive a necessary condition for bias in $R_{c}$ due to Roy selection on unobservables. From (5), (6), and (9),

$$
\left.\frac{\partial \ln \left(R_{c}(s) / R\right)}{\partial \widetilde{\gamma}_{\mathrm{US}}}\right|_{\widetilde{\gamma}_{0}}=\left.\widetilde{\gamma}_{0} \cdot \frac{\partial E[\hat{s} \mid \hat{s}>\underline{s}(s)]}{\partial \widetilde{\gamma}_{\mathrm{US}}}\right|_{\widetilde{\gamma}_{0}}>0
$$

That is, if $R_{c}$ is biased upward by positive selection on unobservables, Roy selection predicts that this bias will be greatest when the relative return to unobserved skill is higher in the destination country relative to the origin country.

We can test condition (10) by following the literature since Juhn et al. (1993) and considering the dispersion of $\widetilde{s}$ for workers of a given country of birth, in each country of residence $\left(\sigma_{0}\right.$ and $\left.\sigma_{\mathrm{US}}\right)$, to proxy for the corresponding returns to unobserved skill. Let $\sigma_{\mathrm{US}}(s)$ be the standard deviation of ln wage conditional on observables, from regression (7), for workers born in each country and resident in the United States. Let $\sigma_{0}(s)$ be the same conditional standard deviation for workers resident in the country of birth. Thus $\sigma_{\mathrm{US}}(s)-\sigma_{0}(s)$ proxies for $\widetilde{\gamma}_{\mathrm{US}}(s)-\widetilde{\gamma}_{0}(s)$, the returns to unobserved skill in the United States relative to the country of birth, specific to each observed skill group.

Estimates of $\hat{\sigma}_{\mathrm{US}}(s)-\hat{\sigma}_{0}(s)$ for each country are given in Table 5 , for three different observed skill groups. The accompanying $p$-values show that these differences are in general highly statistically significant. The final three columns of the table repeat the estimation of $R_{c}$ from Table 1 , this time for each of the three observed skill groups separately. ${ }^{14}$

\footnotetext{
${ }^{14}$ These estimates of $R_{c}$ differ slightly from Table 1 because education categories 5 and 6 are merged into a single new category 5 (13-28 years of schooling). This is because the number of observations in the
} 
Figure 2 tests for the relationship (10) in the data, for each of three observed skill groups. There is no positive correlation between the estimates of $R_{c}$ and the relative returns to unobserved skill, contrary what theory predicts if positive selection is an important source of bias. If anything, the relationship is negative. This suggests that positive selection on unobservables predicted by the Roy model could not be a first-order determinant of the magnitude of the estimates $R_{c}$. Egypt and Yemen are slight outliers at the extreme upper right, thus it is possible that this evidence is consistent with some upward bias from positive selection in those countries. The evidence is inconsistent with a pattern of bias across the other 40 countries.

\subsection{Testing predictions of self-selection due to borrowing constraints}

Theory predicts another reason why migrants might exhibit positive self-selection on unobserved determinants of wages. While migrant selection theory has traditionally focused on Roy selection, a recent literature has stressed borrowing constraints as an important determinant of selection. ${ }^{15}$ Workers with low earnings for unobservable reasons may simply be unable to afford the costs of migration, broadly considered, so that migrants have levels of unobserved skill that exceed the average in the origin country.

Again extending Hanson (2006) to the case of selection on unobservables within observed skill groups, suppose that income $y_{0}$ of a worker in the origin country is a function of unobserved skill. For workers of observed skill $s, y_{0}(s)=\widetilde{\xi}_{0}(s)+\widetilde{\nu}_{0}(s) \hat{s}$, where $\widetilde{\xi}_{0}, \widetilde{\nu}_{0}>0$. Some workers cannot pay the migration cost $C(s)$, which is a function of observed skill, but can borrow it if they hold collateral $\psi C(s), \psi>0$. The condition for migration becomes

$$
\hat{s}>\frac{\psi C(s)-\widetilde{\xi}_{0}(s)}{\widetilde{\nu}_{0}(s)} \equiv \underline{\underline{s}}(s) .
$$

That is, positive selection on unobservables arises within observed skill groups because those with the highest unobserved determinants of earnings are the ones most likely to be

original category 6 is small for a few countries.

${ }^{15} \mathrm{~A}$ wave of studies have stressed the effect of poverty and credit constraints on selection in contemporary migration (Rapoport 2002; Orrenius and Zavodny 2005; Halliday 2006; McKenzie and Rapoport 2010; Hanson 2010; Belot and Hatton 2012; Gould and Moav 2016). This mechanism has also been important in the economic history literature on earlier migration flows (Hatton and Williamson 2006; Abramitzky et al. 2012; Armstrong and Lewis 2012). 
able to acquire the necessary assets. This force for positive selection can act independently of Roy selection (9).

We can use condition (11), as we used (9), to make predictions about patterns the data should contain if selection of this kind is driving the results. Suppose that migration costs are lower for high-observed-skill workers $\left(\frac{\partial C}{\partial s}<0\right)$ and that wealth and the wealth-returns to unobserved skill are greater for workers with higher observed skill $\left(\frac{\partial \widetilde{\xi}_{0}}{\partial s}>0, \frac{\partial \widetilde{\nu}_{0}}{\partial s}>0\right)$. Both of these are plausible: many countries actively encourage high (observed) skill migration while obstructing low (observed) skill migration. And workers in developing countries with higher observed skill typically have greater wealth and work in complex occupations with higher returns to unobserved skill than menial occupations. Suppose furthermore that credit constraints bind for workers without any observed skill $\left(\psi>\frac{\widetilde{\xi}_{0}(s)}{C(s)}\right)$. Together, these imply

$$
\frac{\partial \ln R_{c}(s) / R}{\partial s}=\frac{\partial E[\hat{s} \mid \hat{s}>\underline{\underline{s}}(s)]}{\partial s}<0 .
$$

That is, if the estimates of $R_{c}$ are systematically biased upward from $R$ because of selfselection on unobservables arising from poverty constraints, then we should see estimates of $R_{c}$ decline when higher and higher levels of observed skill are considered separately.

This test is possible with the information already presented in the last three columns of Table 5. In 8 countries, $R_{c}$ is higher for workers with $13+$ years of education than for workers with 5-8 years of education, which is incompatible with (12). In the other 34 countries $R_{c}$ falls somewhat at higher levels of observed skill, which is compatible with (12). The median ratio $R_{c}(5-8$ years $) / R_{c}(13+$ years $)$ is 1.38 . Collectively, this evidence is compatible with modest positive selection on unobservables that induces upward bias in $R_{c}$ as an estimate of $R$ to a degree comparable to the independent estimates of this bias from Table 3. In other words, to the extent that marginal workers who can afford university education can also afford migration, the last column of Table 5 can serve as a lower bound on $R$ for that category of worker.

A second test uses the fact that in the credit-constraint theory of positive selection, unlike in Roy selection, selection on observables and unobservables must go in the same direction. In this theory the poor do not migrate because they do not have the money, and from the 
standpoint of theory it does not matter whether the reason they do not have money is due to observable or unobservable traits. Take Hanson's (2006) observable counterpart to the wealth equation above and suppose that wealth is also positively correlated with observed skill: $y_{0}(s)=\xi_{0}+\nu_{0} s$, where $\xi_{0}, \nu_{0}>0$. Migrants are positively selected on observed skill analogously to (11), and just as above we can derive an observable counterpart to condition (12):

$$
\frac{\partial \ln R / R_{c}(s)}{\partial \ln w_{0}}<0
$$

with the innocuous assumption that income correlates positively with wealth. That is, if positive self-selection on observables arises due to poverty constraints, the degree of positive self-selection should fall as average wages rise.

Figure 3 carries out this test, plotting the degree of selection on observables $\left(\ln R / R_{c}\right)$ against $E\left[w_{0}\right]$ for all countries of birth, and each observed skill group. The pattern predicted by (13) is not present across all the countries at any level of observed skill. For workers of 5-8 years of education this is perhaps no surprise, since there is less scope for positive selection on education. For higher levels of observed skill, the pattern is more informative. For workers with 9-12 years of education, the degree of positive selection on observables is roughly the same in Costa Rica and Argentina as it is in Vietnam and Sierra Leone, despite a fourfold difference in average wages. The conditional mean does fall slightly, from about 1.4 to 1.2 , as the average wage ranges over an order of magnitude. This is consistent with a modest upward bias on $R_{u}$ as an estimate of $R_{c}$ due to selection on observables arising from credit constraints. For the most educated workers $(13+$ years of education $)$, the conditional mean changes little between the average wage of PPP $\$ 300 /$ month and PPP $\$ 1,200 /$ month. It does fall by roughly 0.3 log points over the range PPP $\$ 600-1,200 /$ month. This too is compatible with modest upward bias arising from positive selection on observables due to credit constraints. ${ }^{16}$ The simple theory presented here does not suggest a reason why income that reflects observables should affect credit constraints differently from income that reflects unobservables. ${ }^{17}$

\footnotetext{
${ }^{16}$ At extremely low wages, PPP $\$ 100-250 /$ month, the conditional mean of $\ln R / R_{c}(s)$ rises with the wage for 9-12 years of education and 13+ years of education. This pattern could arise if, in these extremely poor countries, even the university educated face binding credit constraints. This evidence is compatible with binding credit constraints for potential migrants in Cambodia, Egypt, Haiti, Nigeria, Yemen, and perhaps Sierra Leone. In other words, we should consider with caution the estimates $R_{c}$ that greatly exceed 10 .

${ }^{17}$ Note that the global sample of workers here is restricted to employed wage-workers. The poorest of
} 
A third and separate test for bias due to positive selection of this kind takes advantage of information contained in the relative performance of migrants and natives in the U.S. labor market. Suppose that U.S. natives' wages, analogously to (2) and (3), are determined by $w^{*}(s)=\left(\mu_{0}^{*}+\gamma_{0}^{*} s\right)+\widetilde{\gamma}_{0}^{*} \widetilde{s}$ and natives' unobserved skill has mean zero. Migrants' skill is only partially transferable, as in the model advanced by Gould and Moav (2016). Observed skill is transferable from the migrant-origin country to the U.S. in the proportion $\gamma_{\mathrm{US}} / \gamma_{0}$, and unobserved skill is transferable in the proportion $\widetilde{\gamma}_{\mathrm{US}} / \widetilde{\gamma}_{0}$. We can express the wages of a migrant in the U.S. as

$$
E_{\mathrm{US}}\left[\ln w_{\mathrm{US}}\right]=E\left[\ln w^{*}\right]-\left(1-\frac{\gamma_{\mathrm{US}}}{\gamma_{0}}\right) E\left[\ln w^{*}-\ln \underline{w}\right]+\widetilde{\gamma}_{\mathrm{US}} E_{\mathrm{US}}[\hat{s}]
$$

where $\underline{w}^{*}$ is the wage of a U.S. worker with no observable skill (no education, no experience), and $E_{\mathrm{US}}$ denotes expectations for migrant workers in the U.S. The identity (14) states that the average wage of a migrant worker in the U.S. equals the average wage of an observably equivalent U.S. worker, minus the portion of migrant workers' observable wage determinants that do not transfer from the origin country to the U.S., plus the U.S. returns to migrants' unobservable skill. In the limiting case where none of migrants' observable skills are valued in the U.S. market $\left(\gamma_{\mathrm{US}} / \gamma_{0}=0\right)$ and migrants are neutrally selected on unobservables $\left(E_{\mathrm{US}}[\hat{s}]=0\right)$, all migrants regardless of observed or unobserved skill have the earnings of a U.S. teenager with no schooling. From (5) and (6) we have $\ln \frac{R_{c}}{R}=\widetilde{\gamma}_{0} E_{\mathrm{US}}[\hat{s}]$, into which we substitute (14) to get

$$
E_{\mathrm{US}}\left[\ln w_{\mathrm{US}}\right]-E\left[\ln w^{*}\right]=\frac{\widetilde{\gamma}_{\mathrm{US}}}{\widetilde{\gamma}_{0}}\left(\ln R_{c}-\ln R\right)-\left(1-\frac{\gamma_{\mathrm{US}}}{\gamma_{0}}\right) E\left[\ln w^{*}-\ln \underline{w}^{*}\right] .
$$

Intuitively, migrants who are more positively selected on unobserved skill $\left(R_{c}>R\right)$ should earn more relative to natives of the same observable skill, to the extent that their unobserved skill is transferable $\left(\widetilde{\gamma}_{\mathrm{US}} / \widetilde{\gamma}_{0}\right)$. If there are zero returns to migration $(R=1)$, a regression of $R_{c}$ on the native-immigrant wage gap within an observed skill group should have slope representing the transferability of unobserved skill. If that slope is zero, then either unobserved skill is completely untransferable - it does not represent IQ, energy, risk tolerance, or anything else that comes with migrants and has returns in the U.S.- or

the poor - self-employed farmers or small-time informal retailers - are not included and these conclusions regarding credit constraints do not apply to them. 
$R_{c} \approx R$

We calculate $E_{\mathrm{US}}\left[w_{\mathrm{US}}\right]-E\left[w^{*}\right]$ for each country of birth and three observed skill groups in Table 6, always for 35-39 year-old males. This allows us to run the regression (15) nonparametrically in Figure 4.

The slope is generally indistinguishable from zero across most of the support of $R_{c}$, for all three observed skill groups. Two exceptions, in workers with 5-8 years of education, are Cameroon and Morocco. This suggests that either unobserved skill exhibits near-zero transferability to the U.S. labor market, or that estimates of $R_{c}$ do not greatly exceed $R$. Research that compares U.S. immigrants' earnings to their pre-migration earnings estimates that the transferability of foreign unobserved skill is 0.34 shortly after arrival (Jasso et al. 2002), a lower bound on $\widetilde{\gamma}_{\mathrm{US}} / \widetilde{\gamma}_{0}$ since the returns to migrants' unobserved skill are known to rise in the years following arrival (Chiswick and Miller 2012). This suggests that the gap between $R$ and $R_{c}$ is not large.

We can use this information to estimate a rough bound on the selection bias $R_{c} / R$. For the observed skill group with the most positive slope in Figure 4 (5-8 years of schooling), a linear regression of $E_{\mathrm{US}}\left[w_{\mathrm{US}}\right]-E\left[w^{*}\right]$ on $\ln R_{c}$ gives the slope 0.144 (standard error 0.061). If a lower bound on the transferability of unobserved skill for those who have chosen to migrate is 0.34 , this puts an upper bound on $R_{c} / R$ of $e^{(0.144 / 0.34)}=1.53$ for workers with 5-8 years of education. For the group with $13+$ years of schooling, the linear regression slope is 0.031 (standard error 0.043), and the corresponding upper bound on $R_{c} / R$ is $e^{(0.031 / 0.34)}=1.10$. These estimates independently corroborate the approximate magnitude of bias estimated above. The fact that the bias declines with higher observed skill also agrees with the prediction of (12).

These results are consistent with modest systematic bias in $R_{c}$ as an estimator of $R$ due to positive selection on unobservables arising from credit constraints. Incidentally, these results also have implications for the discussion of Roy selection in subsection 3.2. The slopes in Figure 4 further suggest that Roy selection is unlikely to create a large upward bias on $R_{c}$ as an estimate of $R$. A well-known preduction of Roy selection is that positive 
selection on unobservables cannot occur without positive returns to unobservables in the destination country. ${ }^{18}$ The flat slopes in the figure imply either that almost none of migrants' unobserved skill is transferable to the destination country, or that $R_{c} \approx R$. But if migrants' unobserved skill is not transferable, the Roy model predicts negative selection on unobservables. In that case the estimates of $R_{c}$ would generally serve as a lower bound on $R$.

A final and intuitive robustness check is simply to repeat the analysis of Table 1 omitting the poor. These rich microdata allow reestimation by truncating workers who are the most likely to face binding credit constraints. We follow Birdsall et al. (2000), Easterly (2001), and Banerjee and Duflo (2008) in defining workers above PPP $\$ 4 /$ day as having risen above the most grinding poverty into the global "middle class": People living above $\$ 4 /$ day are a small minority in poor countries (Banerjee and Duflo 2008, p. 6) and it is above this income level that families begin to have substantial disposable income. Table 7 shows the estimates of $R_{c}$ after dropping workers below $\$ 1$ /day and $\$ 2 /$ day (the World Bank definitions of extreme poverty and poverty, respectively) as well as $\$ 4 /$ day. The estimates of $R_{c}$ fall somewhat when progressively less-poor workers are truncated, again consistent with a modest upward bias in $R_{c}$ due to positive selection on unobservables arising from credit constraints. In the final column only one of the $R_{c}$ estimates exceeds 10, corroborating the evidence above. The estimates remain large, however, with a median $R_{c}$ of 3.96 even when all workers below $\$ 4$ /day day are truncated. The median ratio of the original estimates (column 1 ) to the estimates for workers above $\$ 4 /$ day (column 4 ) is 1.07. To the extent that $R_{c}$ is a biased measure of $R$ due to credit constraints not faced by the global middle class, this ratio bounds the typical extent of the bias.

\footnotetext{
${ }^{18}$ Formally, if $\widetilde{\gamma}_{\mathrm{US}}=0$ then condition (9) flips to $\widetilde{s}<\frac{\left(\mu_{\mathrm{US}}^{\prime}-\mu_{0}^{\prime}\right)-\pi}{\tilde{\gamma}_{0}}$, and those with below-average unobserved skill choose to migrate. In terms of the stochastic Roy model in Borjas (1991), when earnings at the destination are uncorrelated with earnings at the origin $(\rho=0)$, then as long as $\sigma_{0}>0$, selection must be negative. Intuitively, if all migrants within an observed skill group had exactly the same wage at the destination (zero return to unobserved skill), then those with the most to gain from migration must be those with the lowest levels of unobserved skill - provided that unobserved skill has any positive return in the origin country.
} 


\subsection{Summary of findings}

The various methods used here to places bounds on $R$ broadly agree. Coefficient stability and diverse existing evidence about selection on unobservables imply that for the median country, $R>3.95$ (Table 3 ) and for the $80^{\text {th }}$ percentile country, $R>6.14$. These correspond to lower bounds on the absolute gain per worker per year of $\operatorname{PPP} \$ 13,600$ and PPP $\$ 15,600$, respectively. The corresponding upper bounds on the degree of selection on unobservables, $R / R_{c}$, are 1.12 at the median and 1.26 at the $80^{\text {th }}$ percentile. Various robustness checks corroborate these bounds: The predictions of Roy self-selection are incompatible with $R / R_{c}$ outside this range (Figure 2). The predictions of borrowingconstraint self-selection (Figure 4) are compatible with $R / R_{c}$ in the middle of the range 1.1-1.5 (for the 9-12 years of schooling group). Dropping all workers in poverty leads to $R / R_{c}$ of 1.1 for the median country. In 11 studies allowing point estimates of $R / R_{c}$ for a real migration flow, most values are close to unity and the highest ever recorded is 1.36. In all studies of real migration flows, when there is positive selection on unobservables it is of a degree roughly equal to the degree of selection on observables in extreme cases, and much less in typical cases.

\section{Discussion: Policy barriers and natural barriers}

The place premium $R$ measures an aggregate of two different kinds of costs. In a labor market at full spatial equilibrium workers move until the marginal benefit equals the marginal cost, thus $R=w_{\mathrm{US}} / w_{0}=1+\pi$. Part of the cost $\pi$ could arise from barriers induced by policy such as visa fees, smuggler fees, or the price equivalent of visa rationing or professional licensing restrictions. Another part could arise from barriers largely independent of policy such as transportation costs or nonwage disamenities, such as a compensating differential for being far from home. Since the Elements of Marshall (1892, p. 282) it has been recognized that "the unwillingness to quit home, and to leave old associations, including perhaps some loved cottage and burial-ground, will often turn the scale against a proposal to seek better wages in a new place." 
These two types of migration barriers cannot be cleanly distinguished in the data used here. Beyond that, it is difficult to distinguish 'natural' and 'policy' barriers to migration even in theory. For example, migrant networks are known to be an important determinant of migration costs by reducing search frictions (Munshi 2003) and credit constraints (McKenzie and Rapoport 2010). Costs arising from a small network could be modeled as 'natural' barriers. But networks reflect prior migration flows, and those flows were themselves a consequence of policy. Generations of U.S. 'national origin' quotas were designed expressly to prevent migration from much of Southern Europe, Africa, the Middle East, and Asia, and did so (Higham 2002, p. 312-324). Language barriers and other disamenities of migration, too, can be modeled as 'natural' barriers. But such costs are shaped by policy: for example, at the same time the state of New Hampshire required its driving knowledge exam to be taken exclusively in English, neighboring Vermont allowed the same test to be taken in three foreign languages (Haire et al. 2011).

Here we discuss reasonable priors for the fraction of the place premium that arises from barriers that are unambiguously related to policy. While a quantitative decomposition is impossible, information is available to form reasonable qualitative priors about the fraction of the place premium that arises from policy barriers. To begin with, most people outside the United States are prohibited by default from entering the country and working there unless they acquire a special license from the federal government, a visa. This includes citizens of all 42 countries we study. Such policy barriers have large effects on migration flows. Bertoli and Fernández-Huertas (2015) find that visa requirements cut bilateral migration flows by half at equilibrium, while any new law tightening immigration policy typically reduces inflows by $6 \%$ in the same year Ortega and Peri (2013). Many U.S. visas are tightly rationed, with waiting periods measured in decades. ${ }^{19}$ The United States government spends more on enforcing its immigration restrictions than it spends on all other principal federal law-enforcement agencies combined-including the Federal Bureau of Investigation, the Drug Enforcement Administration, and the Bureau of Alcohol, Tobacco, and Firearms (Meissner et al. 2013, p. 22). It would be strange if cross-border labor markets were unaffected by all of this, given that policies enforced at

\footnotetext{
${ }^{19}$ This includes many categories of family-based visas for citizens of China, India, Mexico, and the Philippines. See U.S. Department of State (2015), Visa Bulletin: Immigrant Numbers for November 2015, $86(9): 1-9$.
} 
borders have large price effects on output prices and other factor prices (e.g. Anderson and Neary 1996). These suggest a reasonable starting prior that the fraction of the wage gap $R$ related to policy is nonzero, even substantial.

An ideal natural experiment to isolate policy costs would require countries that are highly similar to the 42 countries studied above, but do not face policy barriers on U.S. immigration. There are no areas so similar in all other respects as to allow precise decomposition of the 'policy' portion and 'natural' portion of the place premium. There do exist territories free of policy barriers that are nevertheless similar in some respects to foreign countries. People from Puerto Rico and Guam hold U.S. citizenship and can live and work at will to any part of the United States. It is illustrative to estimate $R_{c}$ for these territories.

Table 8 carries out the same exercise in Table 1 for Puerto Rico and Guam. ${ }^{20} R_{c}$ is estimated for all Puerto Rico-born and exclusively for ethnic Puerto Ricans; as well as for all Guam-born and exclusively for ethnic Guamanians. ${ }^{21}$ The results corroborate Ramos's (1992) finding of negative selection on observables for Puerto Ricans $\left(R_{u}<R_{c}\right)$, but suggest positive selection on observables for Guamanians $\left(R_{u}>R_{c}\right)$.

The estimates of $R_{c}$ for these areas without policy barriers lie in the range $1.3-1.5$, substantially above unity. This is compatible with sizeable natural barriers to migration even for workers who face no policy barriers. But these estimates are much smaller than those in Table 1. The ratio for Haiti is several times the size of the ratio for Puerto Rico, even though both countries are close to the United States and have large migrant networks there. The ratio for the Philippines is several times the size of the ratio for Guam, even

\footnotetext{
${ }^{20}$ The only difference from the prior exercise is that the census data do not indicate the year of arrival of Puerto Ricans and Guamanians living in the 50 United States, so we include in all columns those who arrived as children. Dollar wages in Puerto Rico are converted to "mainland PPP" dollars by dividing by the PPP factor 0.86 from Heston et al. (2006). Dollar wages in Guam are converted to mainland purchasing power using figures from OPM (2000, p. 44142) of the US, which determined in a 1998 survey that a basket of basic consumption items (including food at home and away, tobacco, alcohol, furnishings, clothing, domestic services, professional services, personal care, and recreation) cost about $20.3 \%$ more in Guam than in Washington, DC. This figure is not sensitive to different spending patterns at different income levels.

${ }^{21}$ Puerto Rican ethnicity is self-reported in the census for people who live in Puerto Rico or in the 50 United States. "Chamorro" (Guamanian) people are identified in Guam as people who indicate "ethnicity" as "Pacific islander" and indicate that they speak the Chamorro language. "Chamorro" are identified in the US as having been born in Guam and listing "race" as "Guamanian or Chamorro alone".
} 
though both countries are very far from the United States and both likewise have large migrant networks. There are other ways that Puerto Rico and Guam differ from foreign countries - Puerto Rico receives sizeable inflows of Social Security payments, Guam hosts three U.S. military bases - thus these figures are only suggestive.

But Puerto Rico and Guam are not exceptional. It is difficult to find labor markets anywhere on earth that sustain real wage differentials $R_{c}$ much above 1.5 across geographic areas in the absence of policy restrictions on migration. Kennan and Walker (2011, p. 2456) find that by age 34 , men who are free to migrate between U.S. states have exhibited a "home premium" disutility of migration that would typically be offset if their wage in destination states were higher by a factor of $1.14 .^{22}$ Burda (1995, p. 3) finds that $R_{c}$ between West Germany and East Germany collapsed to 1.3 in the years after policy barriers to migration were eliminated and migration flows spiked. Real wage differentials between metropolitan France and French overseas departments/territories, which exhibit no policy barriers to migration, fall in the range $1.2-1.4 .^{23}$ This broad pattern holds in historical episodes of international migration without policy barriers. Abramitzky et al. (2012) find $R_{c}<1.7$ for late $19^{\text {th }}$ century migration from Norway to the United States. ${ }^{24}$ Williamson (1999, p. 124) shows that $R_{c}$ collapsed from as high as 4 to around 1.5 as migration soared from the Mediterranean to the New World 1880-1914, with falling transportation costs and absent policy restrictions.

These estimates suggest limited scope for explaining the very large estimates of $R_{c}$ and $R$ in the preceding sections with natural barriers like pure transportation costs, or Marshall's fondness for home. Wage gaps are an order of magnitude smaller in many settings that exhibit transportation costs and fondness for home, but do not exhibit policy restrictions. A reasonable prior is that a substantial portion of the large gaps measured in this paper

\footnotetext{
${ }^{22}$ In their analysis, a mover type with no disutility from leaving his home state experiences a migration gain that is greater by $20.6 \%-6.3 \%=14.3 \%$, thus the pure disutility of losing the "home premium" could be just offset by a destination-state wage increase of $14.3 \%$ (Kennan and Walker 2011, Tables XI-XII).

${ }^{23}$ Between metropolitan France and faraway Réunion, $R_{c}=1.18$ [the euro wage gap for typical privatesector low-skill workers (ouvriers) is 18,820/17,970, and prices are 12.4\% higher in Réunion (INSEE 2014, pp. 69, 121)]. For Guadeloupe it is 1.35 [the euro wage gap for moderately low-skill males (ouvriers qualifiés) is $15,937 / 13,556$ (INSEE 2010, p. 105), and prices are $14.8 \%$ higher in Guadeloupe (INSEE 2014, p. 121)].

${ }^{24}$ Abramitzky et al. (2012) estimate $R=1.7$, an upper bound on $R_{c}$ due to negative selection on observables for urban workers.
} 
arise from policy barriers, though precisely what portion we cannot estimate here. That portion is likely to vary considerably across different countries.

Under different assumptions about the relative effects of policy and non-policy barriers on $R$, we can construct scenarios for the supply price of labor from different countries. Figure 5 carries out this exercise. The thick black line shows $\bar{w}_{0}$, an upper bound on the unobserved home-country earnings of workers fully equivalent to those observed living in the United States, for 35-39 year old males with 9-12 years of foreign education. These are calculated using the lower bounds on $R$ from Table 3 , column $2(\delta=1, \Pi=1.3)$. The vertical axis shows annual \$PPP wages, and the horizontal axis shows cumulative working-age population of the source countries with $\bar{w}_{0}$ at or below each value. The black line, then, can be interpreted as the upper envelope for the curve of forgone home-country wages for existing migrants. Directly above each country's flat step in that curve is a dash indicating the wages of fully equivalent migrants born and educated in that country who work in the U.S., and a dashed line shows the simple average of that wage across all immigrants. A further dashed line at the top of the graph shows the corresponding U.S. wage for the U.S.-born.

What would the supply curve of foreign labor in the U.S. market look like with a different mix of policy and natural barriers? We cannot estimate that curve because we cannot precisely decompose $R$ into policy and non-policy elements. But Figure 5 also shows what the upper envelope of that supply curve would look like if wage ratios in the absence of policy barriers were 1.5, as discussed above, or the more extreme case of 2.0. Even in the more extreme case, the distortion arising from policy barriers would, at the margin, exceed PPP $\$ 10,000$ per worker per year for over a billion working-age people in the countries studied here. That would place the magnitude of the implied Harberger triangle plausibly in the trillions of dollars per year. This is not an estimate of the distortion from policy barriers, but is a lower bound on the magnitude of the distortion if real wage ratios above 2.0 cannot be sustained without policy barriers.

In one sense the wages-forgone curve in Figure 5 is conservatively high, and the implied loss conservatively low. Subsection 3.3 considered borrowing constraints as a theoretical reason 
for positive selection on unobservables $\left(R>R_{c}\right)$. McKenzie and Rapoport (2010) find that such borrowing constraints induce positive selection among Mexico-U.S. migrants, but when those borrowing constraints are alleviated by migrant networks, selection is negative. Lesser policy barriers to migration would naturally tend to increase the size of migrant networks. This would allow poorer people to migrate, raising $R$ and reducing $\bar{w}_{0}$. In other words, if positive selection arises from borrowing constraints then policy barriers also shape selection. The estimates $\bar{w}_{0}$ are conservatively high to account for extensive positive selection, but the borrowing-constraint theory predicts that such positive selection arises in part from policy barriers themselves.

\section{Conclusion}

We have estimated real wage gaps between migrants from 42 countries in the United States and observably equivalent workers in the origin country. Focusing on male workers in their late thirties with 9-12 years of education, we estimate that for workers from the median country this ratio $\left(R_{c}\right)$ is 4.54 , for the $80^{\text {th }}$ percentile country it is 7.58 , and the working-age population weighted average is 6.83 . We use a variety of independent methods to bound the plausible bias in these ratios as estimates of the real wage gap for fully equivalent workers $(R)$ that could arise from positive selection of migrants on unobservable determinants of wages.

These bounds imply that workers migrating from the median country to the United States raise their real earnings by a factor greater than 3.95 (an absolute gain exceeding $\operatorname{PPP} \$ 13,600 /$ year), while workers from the $80^{\text {th }}$ percentile country raise their real wages by a factor greater than 6.14 (an absolute gain exceeding $\$ 15,600$ per year). Real wage gaps in the hundreds of percent for workers of equal inherent productivity appears to be a striking feature of the current global economy. This independently corroborates

macroeconomic findings of large productivity gaps between countries that arise from places rather than people (Trefler 1993; Caselli 2005; Acemoğlu and Dell 2010; Jones 2016).

It likewise suggests that each type of migration barriers, both natural and policy barriers, 
creates Harberger triangles in the global economy that measure in the trillions of dollars per year. Further research should more precisely estimate rather than simply bound the real wage gaps $R$, and a priority should be to empirically isolate the portion of this place premium that arises from migration policy. Recent research in international trade has made progress in isolating the pure effect on international borders on price wedges, separate from natural barriers (Gopinath et al. 2011). This will be a fruitful direction for migration research as well.

\section{References}

Abramitzky, Ran, Leah Platt Boustan, and Katherine Eriksson, "Europe's Tired, Poor, Huddled Masses: Self-Selection and Economic Outcomes in the Age of Mass Migration," American Economic Review, 2012, 102 (5), 1832-1856.

Acemoğlu, Daron and Melissa Dell, "Productivity Differences Between and Within Countries," American Economic Journal: Macroeconomics, 2010, 2 (1), 169-188.

Akee, Randall, "Errors in self-reported earnings: The role of previous earnings volatility and individual characteristics," Journal of Development Economics, 2011, 96 (2), 409-421.

_ et al., "Who Leaves? Deciphering Immigrant Self-Selection from a Developing Country," Economic Development and Cultural Change, 2010, 58 (2), 323-344.

Altonji, Joseph G, Todd E Elder, and Christopher R Taber, "Selection on Observed and Unobserved Variables: Assessing the Effectiveness of Catholic Schools," Journal of Political Economy, 2005, 113 (1), 151-184.

Ambrosini, J William and Giovanni Peri, "The determinants and the selection of Mexico-US migrants," The World Economy, 2012, 35 (2), 111-151.

_ , Karin Mayr, Giovanni Peri, and Dragos Radu, "The selection of migrants and returnees in Romania," Economics of Transition, 2015, 23 (4), 753-793.

Amuedo-Dorantes, Catalina, Cynthia Bansak, and Susan Pozo, "On the remitting patterns of immigrants: evidence from Mexican survey data," Economic Review, 2005, 90 (1), $37-58$.

Anderson, James E and Eric van Wincoop, "Trade Costs," Journal of Economic Literature, 2004, 42 (3), 691-751.

- and J Peter Neary, "A new approach to evaluating trade policy," Review of Economic Studies, 1996, 63 (1), 107-125.

Armstrong, Alex and Frank D Lewis, "International migration with capital constraints: interpreting migration from the Netherlands to Canada in the 1920s," Canadian Journal of Economics/Revue canadienne d'économique, 2012, 45 (2), 732-754.

Ashenfelter, Orley C., "Comparing Real Wage Rates: Presidential Address," American Economic Review, 2012, 102 (2), 617-642. 
Banerjee, Abhijit V and Esther Duflo, "What Is Middle Class about the Middle Classes around the World?," Journal of Economic Perspectives, 2008, 22 (2), 3-28.

Barham, Bradford and Stephen Boucher, "Migration, remittances, and inequality: estimating the net effects of migration on income distribution," Journal of Development Economics, 1998, 55 (2), 307-331.

Belot, Michèle VK and Timothy J Hatton, "Immigrant Selection in the OECD," Scandinavian Journal of Economics, 2012, 114 (4), 1105-1128.

Benhabib, Jess and Boyan Jovanovic, "Optimal Migration: A World Perspective," International Economic Review, 2012, 53 (2), 321-348.

Berry, William D, Richard C Fording, and Russell L Hanson, "An Annual Cost of Living Index for the American States, 1960-1995," Journal of Politics, 2000, 62 (2), 550-567.

Bertoli, Simone and Jesús Fernández-Huertas, "The size of the cliff at the border," Regional Science and Urban Economics, 2015, 51, 1-6.

Birdsall, Nancy, Carol Graham, and Stefano Pettinato, "Stuck In The Tunnel: Is Globalization Muddling The Middle Class?," Center on Social and Economic Dynamics Working Paper No. 14, Washington, DC: Brookings Institution 2000.

Borjas, George J, "Immigration and Self-Selection," in John M Abowd and Richard B Freeman, eds., Immigration, Trade, and the Labor Market, Cambridge, MA: National Bureau of Economic Research, 1991, pp. 29-76.

- and Rachel M Friedberg, "Recent Trends in the Earnings of New Immigrants to the United States," NBER Working Paper 15406. Cambridge, MA: National Bureau of Economic Research 2009.

Bound, John, Alan B Krueger et al., "The Extent of Measurement Error in Longitudinal Earnings Data: Do Two Wrongs Make a Right?," Journal of Labor Economics, 1991, 9 (1), $1-24$.

Bradford, Scott, "The global welfare and poverty effects of rich nation immigration barriers," Working Paper, Dept. of Economics, Brigham Young University 2015.

Bratsberg, Bernt and Dek Terrell, "School quality and returns to education of US immigrants," Economic Inquiry, 2002, 40 (2), 177-198.

Brücker, Herbert and Cécily Defoort, "Inequality and the self-selection of international migrants: theory and new evidence," International Journal of Manpower, 2009, 30 (7), 742764 .

Budnik, Katarzyna B, "Rationality of Post-Accession Migration," Focus on European Economic Integration, 2009, Q1/09, 57-83.

Burda, Michael C, "Migration and the option value of waiting," Economic and Social Review, 1995, 27 (1), 1-19.

Cameron, A Colin and Pravin K Trivedi, Microeconometrics: Methods and Applications, Cambridge, UK: Cambridge University Press, 2005.

Carnevale, Anthony P, Stephen J Rose, and Ban Cheah, The College Payoff: Education, Occupations, Lifetime Earnings, Washington, DC: Georgetown University Center on Education and the Workforce, 2011.

Caselli, Francesco, "Accounting for cross-country income differences," in Philippe Aghion and 
Steven N. Durlauf, eds., Handbook of Economic Growth, Vol. 1A, Elsevier, 2005, pp. 679-741.

Chiquiar, Daniel and Gordon H Hanson, "International Migration, Self-Selection, and the Distribution of Wages: Evidence from Mexico and the United States," Journal of Political Economy, 2005, 113 (2), 239-281.

Chiswick, Barry, "The Effect of Americanization on the Earnings of Foreign-born Men," Journal of Political Economy, 1978, 86 (5), 897-921.

Chiswick, Barry R and Paul W Miller, "Negative and positive assimilation, skill transferability, and linguistic distance," Journal of Human Capital, 2012, 6 (1), 35-55.

Clemens, Michael A, "Economics and Emigration: Trillion-Dollar Bills on the Sidewalk?," Journal of Economic Perspectives, 2011, 25 (3), 83-106.

_ , Claudio E. Montenegro, and Lant Pritchett, "The Place Premium: Wage Differences for Identical Workers Across the US Border," Working Paper, Harvard Kennedy School of Government 2009.

Collins, William $\mathbf{J}$ and Marianne $\mathbf{H}$ Wanamaker, "Selection and Economic Gains in the Great Migration of African Americans: New Evidence from Linked Census Data," American Economic Journal: Applied Economics, 2014, 6 (1), 220-252.

di Giovanni, Julian, Andrei A Levchenko, and Francesc Ortega, "A global view of crossborder migration," Journal of the European Economic Association, 2015, 13 (1), 168-202.

Dustmann, Christian and Josep Mestres, "Remittances and temporary migration," Journal of Development Economics, 2010, 92 (1), 62-70.

_ , Tommaso Frattini, and Anna Rosso, "The effect of emigration from Poland on Polish wages," Scandinavian Journal of Economics, 2015, 117 (2), 522-564.

Easterly, William, "The middle class consensus and economic development," Journal of Economic Growth, 2001, 6 (4), 317-335.

- and Sergio Rebelo, "Marginal income tax rates and economic growth in developing countries," European Economic Review, 1993, 37 (2), 409-417.

Edwards, Sebastian et al., "How Effective Are Capital Controls?," Journal of Economic Perspectives, 1999, 13 (4), 65-84.

Elsner, Benjamin, "Does emigration benefit the stayers? Evidence from EU enlargement," Journal of Population Economics, 2013, 26 (2), 531-553.

Feliciano, Cynthia, "Educational selectivity in US immigration: How do immigrants compare to those left behind?," Demography, 2005, 42 (1), 131-152.

Fernández-Huertas, Jesús, "New evidence on emigrant selection," Review of Economics and Statistics, 2011, 93 (1), 72-96.

Finger, JM and AJ Yeats, "Effective Protection by Transportation Costs and Tariffs: A Comparison of Magnitudes," Quarterly Journal of Economics, 1976, 90 (1), 169-176.

Friedberg, Rachel, "You Can't Take It with You? Immigrant Assimilation and the Portability of Human Capital," Journal of Labor Economics, 2000, 18 (2), 221-51.

González, Felipe and Edward Miguel, "War and local collective action in Sierra Leone: A comment on the use of coefficient stability approaches," Journal of Public Economics, 2015, 128 (C), 30-33. 
Gopinath, Gita, Pierre-Olivier Gourinchas, Chang-Tai Hsieh, and Nicholas Li, "International prices, costs, and markup differences," American Economic Review, 2011, 101 (6), 2450-2486.

Gould, Eric D. and Omer Moav, "Does High Inequality Attract High Skilled Immigrants?," Economic Journal, 2016, forthcoming.

Haire, Emily R, Allan F Williams, and David F Preusser, "Driver license testing of young novice drivers," Report DOT HS-811-440. Washington, DC: National Highway Traffic Safety Administration 2011.

Halliday, T, "Migration risk and liquidity constraints in El Salvador.," Economic Development and Cultural Change, 2006, 54 (4), 893-925.

Hanson, Gordon H, "Illegal Migration from Mexico to the United States," Journal of Economic Literature, 2006, 44 (4), 869-924.

_ , "International Migration and the Developing World," in Dani Rodrik and Mark Rosenzweig, eds., Handbook of Development Economics, Vol. 5, Elsevier, 2010, pp. 4363-4414.

Hatton, Timothy and Jeffrey Williamson, "International Migration in the Long-Run: Positive Selection, Negative Selection and Policy," in Federico Foders and Rolf J Langhammer, eds., Labor Mobility and the World Economy, Springer, 2006.

Heckman, James J, Lance J Lochner, and Petra E Todd, "Earnings functions, rates of return and treatment effects: The Mincer equation and beyond," in Eric Hanushek and Finis Welch, eds., Handbook of the Economics of Education, Vol. 1, Elsevier, 2006, pp. 307-458.

Hendricks, Lutz, "How Important Is Human Capital for Development? Evidence from Immigrant Earnings," American Economic Review, 2002, 92 (1), 198-219.

_ and Todd Schoellman, "Human Capital and Development Accounting: New Evidence from Wage Gains at Migration," Working Paper, Dept. of Economics, University of North Carolina at Chapel Hill 2016.

Heston, Alan, Robert Summers, and Bettina Aten, "Penn World Tables Version 6.2," Philadelphia, PA: University of Pennsylvania 2006.

Higham, John, Strangers in the Land: Patterns of American Nativism, 1860-1925, New Brunswick: Rutgers University Press, 2002.

Hines, James R, "Three Sides of Harberger Triangles," Journal of Economic Perspectives, 1999, $13(2), 167-188$.

Hummels, David, "Transportation Costs and International Trade in the Second Era of Globalization," Journal of Economic Perspectives, 2007, 21 (3), 131-154.

Imbens, Guildo W, "Sensitivity to Exogeneity Assumptions in Program Evaluation," American Economic Review, 2003, 93 (2), 126-132.

INSEE, Tableaux Économiques Régionaux de Guadeloupe 2009-2010, Paris: Institut national de la statistique et des études économiques, 2010.

_, Tableau économique de La Réunion, Paris: Institut national de la statistique et des études économiques, 2014.

Irarrázabal, Alfonso, Andreas Moxnes, and Luca David Opromolla, "The tip of the iceberg: a quantitative framework for estimating trade costs," Review of Economics and Statistics, 2015, 97 (4), 777-792. 
Jaeger, David A, "Reconciling the old and new census bureau education questions: Recommendations for researchers," Journal of Business 83 Economic Statistics, 1997, 15 (3), 300-309.

Jasso, Guillermina, Mark R Rosenzweig, and James P. Smith, "The Earnings of U.S. Immigrants: World Skill Prices, Skill Transferability and Selectivity," Working Paper, New Immigrant Survey: Princeton University 2002.

Jones, Charles I, "The Facts of Economic Growth," in John B. Taylor and Harald Uhlig, eds., Handbook of Macroeconomics, Vol. 2, forthcoming, 2016.

Juhn, Chinhui, Kevin Murphy, and Brooks Pierce, "Wage Inequality and the Rise in Returns to Skill," Journal of Political Economy, 1993, 101 (3), 410-42.

Kaestner, Robert and Ofer Malamud, "Self-selection and international migration: New evidence from Mexico," Review of Economics and Statistics, 2014, 96 (1), 78-91.

Kennan, John, "Open borders," Review of Economic Dynamics, 2013, 16 (2), L1-L13.

- and James R Walker, "The effect of expected income on individual migration decisions," Econometrica, 2011, 79 (1), 211-251.

Manning, Willard G, "The logged dependent variable, heteroscedasticity, and the retransformation problem," Journal of Health Economics, 1998, 17 (3), 283-295.

Marshall, Alfred, Elements of Economics, Vol. 1, London: MacMillan and Co., 1892.

McKenzie, David and Hillel Rapoport, "Self-selection patterns in Mexico-US migration: the role of migration networks," Review of Economics and Statistics, 2010, 92 (4), 811-821.

_, John Gibson, and Steven Stillman, "How Important Is Selection? Experimental vs. Non-Experimental Measures of the Income Gains from Migration," Journal of the European Economic Association, 2010, 8 (4), 913-945.

Meissner, Doris, Donald M Kerwin, Muzaffar Chishti, and Claire Bergeron, Immigration Enforcement in the United States: The Rise of a Formidable Machinery, Washington, DC: Migration Policy Institute, 2013.

Mian, Atif and Amir Sufi, "What explains the 2007-2009 drop in employment?," Econometrica, 2014, 82 (6), 2197-2223.

Milanovic, Branko, "Global Inequality of Opportunity: How Much of Our Income Is Determined by Where We Live?," Review of Economics and Statistics, 2015, 97 (2), 452-460.

Montenegro, Claudio E and Maximilian L Hirn, "A new disaggregated set of labor market indicators using standardized household surveys from around the world," Background paper prepared for World Development Report 2009: Reshaping Economic Geography. Washington, DC: World Bank 2009.

Munshi, Kaivan, "Networks in the Modern Economy: Mexican Migrants in the US Labor Market," Quarterly Journal of Economics, 2003, 118 (2), 549-599.

OPM, "Office of Personnel Management: Report on 1998 Surveys Used to Determine Cost-ofLiving Allowance in Non-Foreign Areas," Federal Register, 2000, 65 (137), 44103-44173.

Orrenius, Pia M and Madeline Zavodny, "Self-selection among undocumented immigrants from Mexico," Journal of Development Economics, 2005, 78 (1), 215-240.

_ and _, Beside the Golden Door: US Immigration Reform in a New Era of Globalization, Washington, DC: AEI Press, 2010. 
Ortega, Francesc and Giovanni Peri, "The effect of income and immigration policies on international migration," Migration Studies, 2013, 1 (1), 47-74.

Oster, Emily, "Unobservable Selection and Coefficient Stability: Theory and Evidence," Working Paper, Brown University Dept. of Economics 2015.

Ramos, Fernando, "Out-migration and return migration of Puerto Ricans," in George J. Borjas and Richard B. Freeman, eds., Immigration and the Workforce: Economic Consequences for the United States and Source Areas, Chicago: University of Chicago Press, 1992, pp. 49-66.

Rapoport, Hillel, "Migration, credit constraints and self-employment: A simple model of occupational choice, inequality and growth," Economics Bulletin, 2002, 15 (7), 1-5.

Rooth, Dan-Olof and Jan Saarela, "Selection in migration and return migration: Evidence from micro data," Economics Letters, 2007, 94 (1), 90-95.

Rosenzweig, Mark R, "Global wage inequality and the international flow of migrants," Yale University Economics Department Working Paper No. 772010.

Roy, Andrew Donald, "Some thoughts on the distribution of earnings," Oxford Economic Papers, 1951, 3 (2), 135-146.

Semyonov, Moshe and Anastasia Gorodzeisky, "Labor Migration, Remittances and Household Income: A Comparison between Filipino and Filipina Overseas Workers," International Migration Review, 2005, 39 (1), 45-68.

Trefler, Daniel, "International Factor Price Differences: Leontief Was Right!," Journal of Political Economy, 1993, 101 (6), 961-87.

U.S. Census Bureau, "Public Use Microdata Sample: 2000 Census of Population and Housing," PUMS/16-US (RV), Washington, DC: United States Bureau of the Census 2008.

Vollrath, Dietrich, "How important are dual economy effects for aggregate productivity?," Journal of Development Economics, 2009, 88 (2), 325-334.

Williamson, Jeffrey G, "Real wages, inequality and globalization in Latin America before 1940," Revista de Historia Económica/Journal of Iberian and Latin American Economic History, 1999, 17 (S1), 101-142. 
Figure 1: Schematic representation of the wage ratios

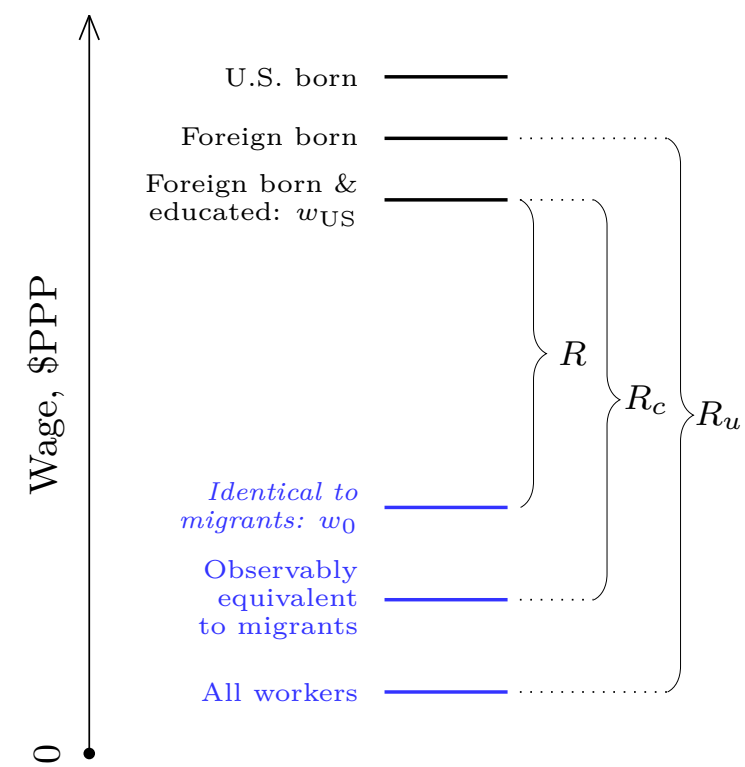

Wage in italics unobserved, others observed. The scenario shown corresponds to positive selection on both observed and unobserved determinants of wages. $R_{u}$ is the unconditional ratio of migrants' wages in the United States to wages in the home country, without adjustment for observable or unobservable differences. $R_{c}$ is the ratio conditional on observable inherent differences like age and education. $R$ is the ratio for fully equivalent workers, accounting for all inherent differences both observable and unobservable. 
Table 1: Wage differences for observably equivalent workers, purchasing power parity

\begin{tabular}{|c|c|c|c|c|c|c|c|c|}
\hline \multirow[b]{3}{*}{ Nigeria } & \multicolumn{2}{|c|}{ No controls } & \multicolumn{2}{|c|}{ Controls } & \multicolumn{4}{|c|}{ Controls, foreign-trained only } \\
\hline & $\ln \hat{R_{u}}$ & s.e. & $\ln \hat{R}_{c}$ & s.e. & $\ln \hat{R}_{c}$ & s.e. & $\hat{R}_{c}$ & s.e. \\
\hline & 2.742 & $(0.038)$ & 2.878 & $(0.117)$ & 2.792 & $(0.119)$ & 16.308 & $(1.209)$ \\
\hline Yemen & 2.414 & $(0.081)$ & 2.783 & $(0.185)$ & 2.716 & $(0.224)$ & 15.114 & $(0.249)$ \\
\hline Haiti & 3.019 & $(0.107)$ & 2.683 & $(0.236)$ & 2.656 & $(0.236)$ & 14.245 & $(1.762)$ \\
\hline Egypt & 2.772 & $(0.027)$ & 2.607 & $(0.078)$ & 2.605 & $(0.088)$ & 13.526 & $(0.642)$ \\
\hline Cambodia & 2.138 & $(0.022)$ & 2.295 & $(0.063)$ & 2.213 & $(0.089)$ & 9.139 & $(0.353)$ \\
\hline Vietnam & 2.300 & $(0.010)$ & 2.257 & $(0.026)$ & 2.128 & $(0.030)$ & 8.395 & $(0.150)$ \\
\hline Ghana & 2.343 & $(0.035)$ & 2.121 & $(0.070)$ & 2.099 & $(0.074)$ & 8.160 & $(0.304)$ \\
\hline India & 2.793 & $(0.009)$ & 2.130 & $(0.025)$ & 2.062 & $(0.027)$ & 7.859 & $(0.099)$ \\
\hline Sierra Leone & 2.087 & $(0.058)$ & 2.054 & $(0.154)$ & 2.029 & $(0.161)$ & 7.608 & $(0.708)$ \\
\hline Cameroon & 2.338 & $(0.072)$ & 1.895 & $(0.196)$ & 2.012 & $(0.194)$ & 7.477 & $(0.381)$ \\
\hline Pakistan & 2.613 & $(0.021)$ & 2.050 & $(0.048)$ & 2.006 & $(0.053)$ & 7.433 & $(0.217)$ \\
\hline Indonesia & 2.238 & $(0.033)$ & 1.948 & $(0.095)$ & 1.956 & $(0.115)$ & 7.069 & (0.098) \\
\hline Nepal & 2.362 & $(0.072)$ & 1.989 & $(0.206)$ & 1.901 & $(0.220)$ & 6.692 & $(0.275)$ \\
\hline Sri Lanka & 2.481 & $(0.047)$ & 1.939 & $(0.117)$ & 1.896 & $(0.130)$ & 6.657 & $(0.265)$ \\
\hline Venezuela & 2.191 & $(0.025)$ & 2.086 & $(0.063)$ & 1.877 & $(0.083)$ & 6.532 & $(0.147)$ \\
\hline Jordan & 1.949 & $(0.039)$ & 1.818 & $(0.092)$ & 1.721 & $(0.115)$ & 5.593 & $(0.292)$ \\
\hline Bangladesh & 1.829 & $(0.034)$ & 1.706 & $(0.081)$ & 1.702 & $(0.086)$ & 5.487 & $(0.268)$ \\
\hline Ecuador & 1.820 & $(0.015)$ & 1.787 & $(0.040)$ & 1.680 & $(0.049)$ & 5.368 & $(0.122)$ \\
\hline Uganda & 2.303 & $(0.071)$ & 1.477 & $(0.180)$ & 1.665 & $(0.195)$ & 5.286 & $(0.292)$ \\
\hline Bolivia & 1.706 & $(0.038)$ & 1.734 & $(0.095)$ & 1.630 & $(0.108)$ & 5.106 & $(0.225)$ \\
\hline Ethiopia & 2.492 & $(0.028)$ & 1.553 & $(0.068)$ & 1.523 & $(0.076)$ & 4.585 & $(0.084)$ \\
\hline Philippines & 1.998 & $(0.009)$ & 1.656 & $(0.021)$ & 1.505 & $(0.024)$ & 4.504 & (0.078) \\
\hline Peru & 1.413 & $(0.022)$ & 1.497 & $(0.044)$ & 1.424 & $(0.047)$ & 4.153 & $(0.113)$ \\
\hline Guyana & 1.666 & $(0.025)$ & 1.451 & $(0.060)$ & 1.403 & $(0.064)$ & 4.067 & $(0.145)$ \\
\hline Jamaica & 1.238 & $(0.033)$ & 1.398 & $(0.056)$ & 1.332 & $(0.060)$ & 3.790 & $(0.110)$ \\
\hline Brazil & 1.579 & $(0.017)$ & 1.362 & $(0.037)$ & 1.327 & $(0.042)$ & 3.769 & $(0.059)$ \\
\hline Nicaragua & 1.372 & $(0.030)$ & 1.397 & $(0.059)$ & 1.293 & $(0.062)$ & 3.643 & $(0.152)$ \\
\hline Panama & 1.429 & $(0.021)$ & 1.446 & $(0.056)$ & 1.291 & $(0.086)$ & 3.635 & $(0.123)$ \\
\hline Chile & 1.221 & $(0.027)$ & 1.324 & $(0.067)$ & 1.276 & $(0.084)$ & 3.582 & $(0.064)$ \\
\hline Guatemala & 1.536 & $(0.025)$ & 1.213 & $(0.078)$ & 1.171 & $(0.080)$ & 3.226 & $(0.107)$ \\
\hline Uruguay & 1.297 & $(0.041)$ & 1.191 & $(0.104)$ & 1.157 & $(0.130)$ & 3.181 & $(0.126)$ \\
\hline Colombia & 1.353 & $(0.013)$ & 1.195 & $(0.030)$ & 1.121 & $(0.034)$ & 3.068 & $(0.056)$ \\
\hline South Africa & 1.389 & $(0.037)$ & 1.193 & $(0.090)$ & 1.094 & $(0.107)$ & 2.985 & $(0.121)$ \\
\hline Paraguay & 1.168 & $(0.074)$ & 1.016 & $(0.156)$ & 1.067 & $(0.179)$ & 2.907 & $(0.082)$ \\
\hline Thailand & 1.335 & $(0.022)$ & 1.242 & $(0.062)$ & 1.040 & $(0.081)$ & 2.828 & $(0.129)$ \\
\hline Turkey & 1.246 & $(0.028)$ & 1.122 & $(0.071)$ & 1.006 & $(0.087)$ & 2.735 & $(0.017)$ \\
\hline Belize & 1.250 & $(0.048)$ & 0.945 & $(0.129)$ & 0.968 & $(0.158)$ & 2.633 & $(0.247)$ \\
\hline Mexico & 1.001 & $(0.014)$ & 1.045 & $(0.034)$ & 0.951 & $(0.035)$ & 2.589 & $(0.025)$ \\
\hline Argentina & 1.057 & $(0.024)$ & 1.053 & $(0.067)$ & 0.911 & $(0.089)$ & 2.486 & $(0.160)$ \\
\hline Costa Rica & 0.963 & (0.028) & 0.870 & $(0.074)$ & 0.786 & $(0.087)$ & 2.194 & $(0.061)$ \\
\hline Dominican Rep & 0.890 & $(0.016)$ & 0.758 & $(0.049)$ & 0.734 & $(0.051)$ & 2.084 & $(0.066)$ \\
\hline Morocco & 1.402 & $(0.041)$ & 0.881 & $(0.087)$ & 0.706 & $(0.105)$ & 2.026 & $(0.107)$ \\
\hline
\end{tabular}

Estimates with controls are for 35-39 year-old males with 9-12 years of education. Standard errors in parentheses (robust for $\ln \hat{R}_{c}$, bootstrapped for $\hat{R}_{c}$ ). 
Table 2: Wage differences for observably equivalent workers, official exchange rates

\begin{tabular}{|c|c|c|c|c|c|c|c|c|}
\hline \multirow[b]{3}{*}{ Cambodia } & \multicolumn{2}{|c|}{ No controls } & \multicolumn{2}{|c|}{ Controls } & \multicolumn{4}{|c|}{ Controls, foreign-trained only } \\
\hline & $\ln \hat{R_{u}}$ & s.e. & $\ln \hat{R}_{c}$ & s.e. & $\ln \hat{R}_{c}$ & s.e. & $\hat{R}_{c}$ & s.e. \\
\hline & 3.986 & $(0.022)$ & 4.143 & $(0.063)$ & 4.061 & $(0.089)$ & 58.005 & $(2.238)$ \\
\hline Haiti & 4.304 & $(0.107)$ & 3.967 & $(0.236)$ & 3.941 & $(0.236)$ & 51.457 & $(6.366)$ \\
\hline Vietnam & 3.998 & $(0.010)$ & 3.955 & $(0.026)$ & 3.826 & $(0.030)$ & 45.876 & $(0.821)$ \\
\hline Nepal & 4.208 & $(0.072)$ & 3.835 & $(0.206)$ & 3.747 & $(0.220)$ & 42.387 & $(1.744)$ \\
\hline India & 4.399 & $(0.009)$ & 3.736 & $(0.025)$ & 3.668 & $(0.027)$ & 39.166 & $(0.493)$ \\
\hline Nigeria & 3.601 & $(0.038)$ & 3.737 & $(0.117)$ & 3.651 & $(0.119)$ & 38.505 & $(2.854)$ \\
\hline Egypt & 3.646 & $(0.027)$ & 3.480 & $(0.078)$ & 3.479 & $(0.088)$ & 32.413 & $(1.539)$ \\
\hline Ethiopia & 4.430 & $(0.028)$ & 3.491 & $(0.068)$ & 3.461 & $(0.076)$ & 31.842 & $(0.580)$ \\
\hline Uganda & 4.073 & $(0.071)$ & 3.247 & $(0.180)$ & 3.435 & $(0.195)$ & 31.039 & $(1.712)$ \\
\hline Pakistan & 4.024 & $(0.021)$ & 3.461 & $(0.048)$ & 3.417 & $(0.053)$ & 30.472 & $(0.889)$ \\
\hline Sri Lanka & 3.953 & $(0.047)$ & 3.412 & $(0.117)$ & 3.368 & $(0.130)$ & 29.029 & (1.154) \\
\hline Sierra Leone & 3.408 & $(0.058)$ & 3.375 & $(0.154)$ & 3.351 & $(0.161)$ & 28.523 & $(2.654)$ \\
\hline Ghana & 3.505 & $(0.035)$ & 3.283 & $(0.070)$ & 3.261 & $(0.074)$ & 26.082 & $(0.971)$ \\
\hline Indonesia & 3.493 & $(0.033)$ & 3.203 & $(0.095)$ & 3.210 & $(0.115)$ & 24.780 & $(0.342)$ \\
\hline Bangladesh & 3.317 & $(0.034)$ & 3.193 & $(0.081)$ & 3.190 & $(0.086)$ & 24.290 & (1.187) \\
\hline Cameroon & 3.485 & $(0.072)$ & 3.042 & $(0.196)$ & 3.159 & $(0.194)$ & 23.549 & $(1.200)$ \\
\hline Philippines & 3.495 & $(0.009)$ & 3.153 & $(0.021)$ & 3.002 & $(0.024)$ & 20.120 & $(0.349)$ \\
\hline Guyana & 3.197 & $(0.025)$ & 2.983 & $(0.060)$ & 2.935 & $(0.064)$ & 18.815 & $(0.672)$ \\
\hline Yemen & 2.622 & $(0.081)$ & 2.991 & $(0.185)$ & 2.923 & $(0.224)$ & 18.597 & $(0.306)$ \\
\hline Nicaragua & 2.834 & $(0.030)$ & 2.859 & $(0.059)$ & 2.755 & $(0.062)$ & 15.718 & $(0.654)$ \\
\hline Bolivia & 2.724 & $(0.038)$ & 2.751 & $(0.095)$ & 2.648 & $(0.108)$ & 14.124 & $(0.623)$ \\
\hline Jordan & 2.847 & $(0.039)$ & 2.715 & $(0.092)$ & 2.619 & $(0.115)$ & 13.717 & $(0.716)$ \\
\hline Paraguay & 2.467 & $(0.074)$ & 2.315 & $(0.156)$ & 2.367 & $(0.179)$ & 10.664 & $(0.299)$ \\
\hline Peru & 2.286 & $(0.022)$ & 2.369 & $(0.044)$ & 2.296 & $(0.047)$ & 9.938 & $(0.271)$ \\
\hline Thailand & 2.583 & $(0.022)$ & 2.489 & $(0.062)$ & 2.287 & $(0.081)$ & 9.843 & $(0.449)$ \\
\hline Venezuela & 2.542 & $(0.025)$ & 2.437 & $(0.063)$ & 2.228 & $(0.083)$ & 9.280 & $(0.208)$ \\
\hline Colombia & 2.454 & $(0.013)$ & 2.296 & $(0.030)$ & 2.222 & $(0.034)$ & 9.228 & $(0.168)$ \\
\hline Ecuador & 2.326 & $(0.015)$ & 2.293 & $(0.040)$ & 2.187 & $(0.049)$ & 8.906 & $(0.202)$ \\
\hline South Africa & 2.466 & $(0.037)$ & 2.270 & $(0.090)$ & 2.171 & $(0.107)$ & 8.766 & $(0.356)$ \\
\hline Chile & 2.035 & $(0.027)$ & 2.138 & $(0.067)$ & 2.090 & $(0.084)$ & 8.084 & $(0.145)$ \\
\hline Brazil & 2.195 & $(0.017)$ & 1.978 & $(0.037)$ & 1.943 & $(0.042)$ & 6.979 & $(0.109)$ \\
\hline Guatemala & 2.301 & $(0.025)$ & 1.978 & $(0.078)$ & 1.936 & $(0.080)$ & 6.930 & $(0.230)$ \\
\hline Panama & 1.898 & $(0.021)$ & 1.914 & $(0.056)$ & 1.759 & $(0.086)$ & 5.808 & $(0.196)$ \\
\hline Dominican Rep & 1.915 & $(0.016)$ & 1.783 & $(0.049)$ & 1.759 & $(0.051)$ & 5.807 & $(0.185)$ \\
\hline Morocco & 2.384 & $(0.041)$ & 1.863 & $(0.087)$ & 1.687 & $(0.105)$ & 5.406 & $(0.286)$ \\
\hline Turkey & 1.780 & $(0.028)$ & 1.656 & $(0.071)$ & 1.540 & $(0.087)$ & 4.665 & $(0.030)$ \\
\hline Costa Rica & 1.684 & $(0.028)$ & 1.592 & $(0.074)$ & 1.507 & $(0.087)$ & 4.515 & $(0.125)$ \\
\hline Jamaica & 1.403 & $(0.033)$ & 1.563 & $(0.056)$ & 1.498 & $(0.060)$ & 4.471 & $(0.130)$ \\
\hline Argentina & 1.558 & $(0.024)$ & 1.554 & (0.067) & 1.412 & $(0.089)$ & 4.104 & $(0.263)$ \\
\hline Belize & 1.684 & (0.048) & 1.379 & $(0.129)$ & 1.401 & $(0.158)$ & 4.060 & $(0.381)$ \\
\hline Uruguay & 1.499 & $(0.041)$ & 1.393 & $(0.104)$ & 1.359 & $(0.130)$ & 3.892 & $(0.155)$ \\
\hline Mexico & 1.398 & $(0.014)$ & 1.442 & $(0.034)$ & 1.348 & $(0.035)$ & 3.850 & $(0.037)$ \\
\hline
\end{tabular}

Estimates with controls are for 35-39 year-old males with 9-12 years of education. Standard errors in parentheses (robust for $\ln \hat{R}_{c}$, bootstrapped for $\hat{R}_{c}$ ). 
Table 3: Lower bounds on $R$ from coefficient stability test

\begin{tabular}{|c|c|c|c|c|c|c|}
\hline & \multirow[t]{2}{*}{$\left.R_{c}\right|_{\delta=0}$} & \multicolumn{2}{|c|}{ Bound on $\left.R\right|_{\delta=1}$} & \multirow[t]{2}{*}{$\left.\delta\right|_{R=1}$} & \multirow[t]{2}{*}{$R_{u} / R_{c}$} & \multirow[t]{2}{*}{$\$$ gain } \\
\hline & & $\Pi=1.3$ & $\Pi=2.0$ & & & \\
\hline Nigeria & 16.308 & $>15.764$ & $>14.565$ & 82.319 & 1.022 & $>16,611$ \\
\hline Yemen & 15.114 & $>16.368$ & $>19.713$ & -34.074 & 0.921 & $>23,475$ \\
\hline Haiti & 14.245 & $>4.874$ & $>0.861$ & 2.477 & 1.153 & $>4,742$ \\
\hline Egypt & 13.526 & $>12.116$ & $>9.372$ & 23.661 & 1.096 & $>16,766$ \\
\hline Cambodia & 9.139 & $>9.151$ & $>9.179$ & -1669.983 & 0.999 & $>21,352$ \\
\hline Vietnam & 8.395 & $>7.554$ & $>5.904$ & 20.152 & 1.079 & $>15,432$ \\
\hline Ghana & 8.160 & $>6.232$ & $>3.323$ & 7.789 & 1.165 & $>12,810$ \\
\hline India & 7.859 & $>5.930$ & $>3.074$ & 7.322 & 1.415 & $>14,317$ \\
\hline Sierra Leone & 7.608 & $>6.269$ & $>3.991$ & 10.484 & 1.098 & $>12,789$ \\
\hline Cameroon & 7.477 & $>6.287$ & $>4.196$ & 11.608 & 1.240 & $>14,860$ \\
\hline Pakistan & 7.433 & $>5.847$ & $>3.615$ & 8.358 & 1.361 & $>13,845$ \\
\hline Indonesia & 7.069 & $>6.191$ & $>4.545$ & 14.759 & 1.222 & $>14,903$ \\
\hline Nepal & 6.692 & $>5.286$ & $>3.048$ & 8.058 & 1.314 & $>9,244$ \\
\hline Sri Lanka & 6.657 & $>5.328$ & $>3.169$ & 8.514 & 1.343 & $>12,218$ \\
\hline Venezuela & 6.532 & $>5.778$ & $>4.339$ & 15.287 & 1.169 & $>14,995$ \\
\hline Jordan & 5.593 & $>5.012$ & $>3.882$ & 15.715 & 1.150 & $>14,406$ \\
\hline Bangladesh & 5.487 & $>5.077$ & $>4.236$ & 21.919 & 1.134 & $>14,170$ \\
\hline Ecuador & 5.368 & $>5.092$ & $>4.504$ & 31.920 & 1.067 & $>13,537$ \\
\hline Uganda & 5.286 & $>4.242$ & $>2.540$ & 7.572 & 1.413 & $>12,140$ \\
\hline Bolivia & 5.106 & $>4.890$ & $>4.421$ & 37.767 & 1.073 & $>14,697$ \\
\hline Ethiopia & 4.585 & $>3.240$ & $>2.091$ & 4.388 & 1.685 & $>9,247$ \\
\hline Philippines & 4.504 & $>3.475$ & $>1.897$ & 5.802 & 1.404 & $>9,980$ \\
\hline Peru & 4.153 & $>4.106$ & $>3.996$ & 122.911 & 1.024 & $>15,375$ \\
\hline Guyana & 4.067 & $>1.902$ & $>0.495$ & 1.846 & 1.249 & $>5,042$ \\
\hline Jamaica & 3.790 & $>3.788$ & $>3.784$ & 2681.692 & 1.001 & $>15,605$ \\
\hline Brazil & 3.769 & $>3.400$ & $>2.674$ & 12.887 & 1.255 & $>15,019$ \\
\hline Nicaragua & 3.643 & $>3.430$ & $>2.980$ & 21.439 & 1.095 & $>12,488$ \\
\hline Panama & 3.635 & $>3.451$ & $>3.058$ & 24.861 & 1.101 & $>13,668$ \\
\hline Chile & 3.582 & $>3.564$ & $>3.523$ & 258.013 & 1.012 & $>15,971$ \\
\hline Guatemala & 3.226 & $>2.617$ & $>1.607$ & 5.603 & 1.336 & $>9,347$ \\
\hline Uruguay & 3.181 & $>3.023$ & $>2.685$ & 22.757 & 1.134 & $>20,241$ \\
\hline Colombia & 3.068 & $>2.835$ & $>2.356$ & 14.151 & 1.207 & $>11,282$ \\
\hline South Africa & 2.985 & $>2.523$ & $>1.703$ & 6.495 & 1.504 & $>16,207$ \\
\hline Paraguay & 2.907 & $>2.752$ & $>2.421$ & 19.464 & 1.167 & $>16,561$ \\
\hline Thailand & 2.828 & $>2.396$ & $>1.628$ & 6.275 & 1.521 & $>8,920$ \\
\hline Turkey & 2.735 & $>1.949$ & $>1.043$ & 2.972 & 1.344 & $>7,128$ \\
\hline Belize & 2.633 & $>2.248$ & $>1.554$ & 6.120 & 1.337 & $>12,006$ \\
\hline Mexico & 2.589 & $>2.557$ & $>2.484$ & 76.853 & 1.034 & $>10,523$ \\
\hline Argentina & 2.486 & $>2.364$ & $>2.101$ & 18.042 & 1.177 & $>12,135$ \\
\hline Costa Rica & 2.194 & $>2.096$ & $>1.885$ & 17.234 & 1.178 & $>9,563$ \\
\hline Dominican Rep & 2.084 & $>1.899$ & $>1.530$ & 7.916 & 1.258 & $>7,728$ \\
\hline Morocco & 2.026 & $>1.665$ & $>1.054$ & 3.600 & 1.894 & $>5,876$ \\
\hline
\end{tabular}

Lower bounds on dollar gain (col. 6) are PPP $\$ /$ year using $\left.R\right|_{\delta=1, \Pi=1.3}$ from col. 2. 
Table 4: Selection in the literature

\begin{tabular}{|c|c|c|c|c|}
\hline Migrant origin & $R_{u} / R_{c}$ & $R_{c} / R$ & $\delta$ & Source \\
\hline Micronesia $\rightarrow$ US & 0.71 & 1.36 & -0.90 & Akee et al. $(2010)^{\mathrm{a}}$ \\
\hline Tonga $\rightarrow$ NZ & 1.38 & 1.33 & +0.89 & McKenzie et al. $(2010)^{\mathrm{b}}$ \\
\hline Poland $\rightarrow$ UK & - & 1.14 & - & Budnik $(2009)^{\mathrm{c}}$ \\
\hline US Blacks 1920s $\rightarrow$ North & 1.11 & 1.05 & 0.48 & Collins and Wanamaker (2014)d \\
\hline Finland $\rightarrow$ Sweden & 0.86 & 1.04 & -0.24 & Rooth and Saarela $(2007)^{\mathrm{e}}$ \\
\hline Norway $1900 \rightarrow$ US & - & 1.04 & & Abramitzky et al. $(2012)^{\mathrm{f}}$ \\
\hline Lithuania $\rightarrow$ UK/Ireland & $<1$ & $\sim 1$ & $\sim 0$ & Elsner (2013, p. 545) \\
\hline Poland $\rightarrow$ UK & - & $\sim 1$ & $\sim 0$ & Dustmann et al. (2015, p. 535) \\
\hline Israel $\rightarrow$ US & $>1$ & $\sim 1$ & $\sim 0$ & Gould and Moav (2016) \\
\hline Mexico $\rightarrow$ US & 0.85 & 0.90 & +0.65 & Fernández-Huertas (2011)g \\
\hline Mexico $\rightarrow$ US & 0.89 & 0.73 & +2.25 & Ambrosini and Peri $(2012)^{\mathrm{h}}$ \\
\hline Romania $\rightarrow$ US & 1.20 & - & - & Ambrosini et al. $(2015)^{\mathrm{i}}$ \\
\hline Nicaragua $\rightarrow$ US & 0.89 & - & - & Barham and Boucher $(1998)^{\mathrm{j}}$ \\
\hline Puerto Rico $\rightarrow$ US & 0.87 & - & - & $\operatorname{Ramos}(1992)^{\mathrm{k}}$ \\
\hline Romania $\rightarrow$ Spain & 0.87 & - & - & Ambrosini et al. $(2015)^{\mathrm{i}}$ \\
\hline Poor countries $^{1} \rightarrow$ US & $>1$ & $>1$ & $<0.33$ & Hendricks and Schoellman (2016, Fig. 4) \\
\hline Poorest countries ${ }^{1} \rightarrow$ US & $>1$ & $>1$ & $\approx 1$ & Hendricks and Schoellman (2016, Fig. 4) \\
\hline
\end{tabular}

${ }^{a} \ln$ earnings of adult male nonmigrants $=8.075$ (Table 1, p. 330), ln earnings if observably equivalent to migrants $=7.73$ (Table 5, p. 335), thus $e^{(7.73-8.075)}=0.708$; Table 6, p. 338: $e^{0.309}=1.36 ;(\ln 1.36) /(\ln 0.71)=-0.897$. Note this does not conflict with Akee's finding of positive selection on observed education, since this negative selection on observables includes age (youth both migrate more and earn less).

b p. 925: $(34+56) /(34+31)=1.38$; p. 930: $\beta_{\mathrm{OLS}}$ "31\%-35\% higher" than $\beta_{\mathrm{IV}-\mathrm{TT}}$; thus $(\ln 1.33) /(\ln 1.38)=0.885$.

${ }^{c}$ Table 5, p. 76: $e^{(0.931-0.802)}=1.14$. Insufficient information to calculate $R_{u} / R_{o}$.

d Table 4, p. 233: $e^{(0.142-0.0495)}=1.097 ; e^{(0.0495)}=1.051 ;$ thus $(\ln 1.051) /(\ln 1.108)=0.483$.

e Table 2, p. 94: $e^{(-0.115-0.037)}=0.859 ; e^{0.037}=1.038 ;$ thus $(\ln 1.038) /(\ln 0.859)=-0.24$.

f Table 3, p. 1847: $e^{(0.586-0.542)}$.

g p. 85: $e^{(-0.16)}=0.85 ; e^{(-0.26-(-0.16))}=0.90 ;$ thus $(\ln 0.9) /(\ln 0.85)=0.648$.

h Table 2, p. 125: $e^{(-0.12)}=0.89 ; \exp ^{(-0.27)}=0.763 ;$ thus $(\ln 0.763) /(\ln 0.887)=2.25$.

ip. 778 .

j Table 6, p. 325: $\left(y_{\text {foreign }} / 163.9\right) /\left(y_{\text {foreign }} / 146.2\right)=0.892$.

${ }^{\mathrm{k}}$ Table 2.3-2.4, p. 59: $R_{u}=e^{(5.11-4.14)}=2.63$; Table 2.9, p. 65: $R_{c}=e^{(1.967-0.876)}=2.98$.

${ }^{1}$ Here 'poor countries' includes those between $1 / 2$ and $1 / 16$ of U.S. GDP per capita, a group comprising 36 of the 42 countries studied in this paper. 'Poorest countries' includes those less than 1/16 of U.S. GDP per capita, a group that includes the other eight countries studied here. The source does not report these estimates for individual countries in each group. 
Table 5: Relative returns to unobserved determinants of wages, U.S. versus home country

\begin{tabular}{|c|c|c|c|c|c|c|c|c|c|}
\hline \multirow{3}{*}{$\begin{array}{l}\text { Years educ.: } \\
\text { Nigeria }\end{array}$} & \multicolumn{6}{|c|}{$\hat{\sigma}_{\mathrm{US}}-\hat{\sigma}_{0},\left[p\left(H_{0}: \sigma_{\mathrm{US}}=\sigma_{0}\right)\right]$} & \multicolumn{3}{|c|}{$R_{c}$} \\
\hline & \multicolumn{2}{|c|}{$5-8$} & \multicolumn{2}{|c|}{$9-12$} & \multicolumn{2}{|c|}{$13+$} & $5-8$ & $9-12$ & $13+$ \\
\hline & -0.575 & [0.05] & -0.512 & {$[0.00]$} & -0.589 & {$[0.00]$} & 13.762 & 16.636 & 18.380 \\
\hline Yemen & 0.302 & {$[0.19]$} & 0.439 & {$[0.00]$} & 0.497 & {$[0.00]$} & 14.163 & 15.015 & 13.953 \\
\hline Haiti & -0.935 & {$[0.00]$} & -0.919 & {$[0.00]$} & -0.589 & {$[0.00]$} & 17.791 & 14.168 & 14.036 \\
\hline Egypt & 0.450 & {$[0.00]$} & 0.508 & {$[0.00]$} & 0.457 & {$[0.00]$} & 16.594 & 13.769 & 17.569 \\
\hline Cambodia & -0.194 & {$[0.00]$} & -0.123 & {$[0.00]$} & 0.015 & {$[0.26]$} & 8.552 & 9.164 & 9.021 \\
\hline Vietnam & 0.184 & {$[0.00]$} & 0.100 & {$[0.00]$} & 0.224 & {$[0.00]$} & 8.343 & 8.402 & 8.197 \\
\hline Ghana & -0.247 & {$[0.64]$} & -0.104 & {$[0.01]$} & -0.173 & {$[0.00]$} & 8.961 & 8.223 & 6.400 \\
\hline India & 0.320 & {$[0.00]$} & 0.116 & {$[0.00]$} & 0.180 & {$[0.00]$} & 8.655 & 8.171 & 7.760 \\
\hline Sierra Leone & 1.383 & {$[0.00]$} & 0.177 & {$[0.00]$} & 0.098 & {$[0.89]$} & 8.316 & 7.605 & 7.849 \\
\hline Cameroon & -0.744 & {$[0.00]$} & 0.091 & {$[0.18]$} & 0.062 & {$[0.09]$} & 20.421 & 7.558 & 6.751 \\
\hline Pakistan & 0.441 & {$[0.00]$} & 0.313 & {$[0.00]$} & 0.326 & {$[0.00]$} & 6.815 & 7.558 & 7.316 \\
\hline Indonesia & 0.086 & {$[0.08]$} & 0.198 & {$[0.00]$} & 0.301 & {$[0.00]$} & 10.001 & 7.381 & 6.277 \\
\hline Nepal & 0.521 & {$[0.01]$} & 0.414 & {$[0.00]$} & 0.327 & {$[0.76]$} & 6.810 & 7.168 & 7.100 \\
\hline Sri Lanka & 0.140 & {$[0.33]$} & 0.336 & {$[0.00]$} & 0.323 & {$[0.00]$} & 5.399 & 6.877 & 5.924 \\
\hline Venezuela & 0.198 & {$[0.02]$} & 0.445 & {$[0.00]$} & 0.417 & {$[0.00]$} & 6.862 & 6.541 & 6.191 \\
\hline Jordan & 0.153 & {$[0.18]$} & 0.412 & {$[0.00]$} & 0.374 & {$[0.00]$} & 6.865 & 5.586 & 4.834 \\
\hline Bangladesh & 0.369 & {$[0.00]$} & 0.192 & {$[0.00]$} & 0.281 & {$[0.00]$} & 5.379 & 5.563 & 4.306 \\
\hline Ecuador & 0.114 & {$[0.00]$} & 0.214 & {$[0.00]$} & 0.225 & {$[0.00]$} & 7.016 & 5.324 & 3.954 \\
\hline Uganda & 0.123 & {$[0.59]$} & -0.199 & {$[0.48]$} & 0.109 & {$[0.29]$} & 11.597 & 5.272 & 3.336 \\
\hline Bolivia & 0.141 & {$[0.00]$} & 0.130 & {$[0.00]$} & 0.009 & {$[0.03]$} & 5.937 & 5.007 & 3.451 \\
\hline Ethiopia & 0.180 & {$[0.03]$} & 0.184 & {$[0.00]$} & 0.327 & {$[0.00]$} & 9.758 & 4.620 & 2.935 \\
\hline Philippines & -0.053 & {$[0.30]$} & -0.069 & {$[0.00]$} & 0.078 & {$[0.00]$} & 6.423 & 4.499 & 3.291 \\
\hline Peru & 0.022 & {$[0.94]$} & 0.067 & {$[0.00]$} & 0.043 & {$[0.00]$} & 4.845 & 4.129 & 2.785 \\
\hline Guyana & 0.327 & {$[0.00]$} & 0.246 & {$[0.00]$} & -0.007 & {$[0.60]$} & 3.177 & 4.060 & 3.259 \\
\hline Brazil & 0.395 & {$[0.00]$} & 0.244 & {$[0.00]$} & 0.282 & {$[0.00]$} & 4.922 & 3.792 & 2.712 \\
\hline Jamaica & 0.235 & {$[0.00]$} & 0.255 & {$[0.00]$} & 0.109 & {$[0.00]$} & 3.752 & 3.741 & 2.749 \\
\hline Panama & 0.260 & {$[0.02]$} & 0.205 & {$[0.00]$} & 0.154 & {$[0.00]$} & 3.556 & 3.648 & 3.061 \\
\hline Nicaragua & 0.247 & {$[0.00]$} & 0.177 & {$[0.00]$} & 0.021 & {$[0.87]$} & 3.701 & 3.609 & 2.250 \\
\hline Chile & 0.264 & {$[0.00]$} & 0.230 & {$[0.00]$} & 0.293 & {$[0.00]$} & 3.627 & 3.590 & 2.483 \\
\hline Guatemala & 0.093 & {$[0.02]$} & 0.010 & {$[0.36]$} & -0.028 & {$[0.89]$} & 4.358 & 3.237 & 2.327 \\
\hline Uruguay & -0.000 & [0.98] & 0.019 & {$[0.58]$} & 0.400 & {$[0.00]$} & 3.602 & 3.216 & 2.716 \\
\hline South Africa & 0.198 & {$[0.29]$} & 0.135 & {$[0.00]$} & 0.220 & {$[0.00]$} & 3.872 & 3.074 & 2.016 \\
\hline Colombia & 0.205 & {$[0.00]$} & 0.166 & {$[0.00]$} & 0.330 & {$[0.00]$} & 3.759 & 3.044 & 1.993 \\
\hline Thailand & -0.212 & {$[0.00]$} & 0.110 & {$[0.00]$} & 0.291 & {$[0.00]$} & 3.995 & 2.821 & 2.069 \\
\hline Paraguay & 0.147 & {$[0.28]$} & -0.016 & {$[0.87]$} & 0.397 & {$[0.00]$} & 2.124 & 2.820 & 1.748 \\
\hline Turkey & 0.310 & {$[0.00]$} & 0.499 & {$[0.00]$} & 0.562 & {$[0.00]$} & 3.072 & 2.741 & 2.867 \\
\hline Belize & 0.108 & {$[0.04]$} & 0.293 & {$[0.00]$} & 0.246 & {$[0.00]$} & 3.295 & 2.594 & 2.013 \\
\hline Mexico & 0.148 & {$[0.00]$} & 0.164 & {$[0.00]$} & 0.143 & {$[0.00]$} & 3.170 & 2.575 & 1.621 \\
\hline Argentina & 0.238 & {$[0.00]$} & 0.206 & {$[0.00]$} & 0.339 & {$[0.00]$} & 2.600 & 2.566 & 2.284 \\
\hline Costa Rica & 0.402 & {$[0.00]$} & 0.390 & {$[0.00]$} & 0.188 & {$[0.00]$} & 2.547 & 2.194 & 1.605 \\
\hline Dominican Rep & 0.300 & {$[0.00]$} & 0.216 & {$[0.00]$} & 0.223 & {$[0.00]$} & 2.299 & 2.076 & 1.608 \\
\hline Morocco & 0.628 & {$[0.00]$} & 0.255 & {$[0.00]$} & 0.344 & {$[0.00]$} & 1.363 & 2.033 & 2.173 \\
\hline
\end{tabular}

$p$-values of $F$ test for equality of standard deviations given in square brackets (due to rounding, ' 0.00 ' $=<$ 0.005). These estimates of $R_{c}$ differ slightly from Table 1 because education categories 5 and 6 are merged into a single new category 5 (13-28 years of schooling). 
Figure 2: Relative returns to unobserved skill, U.S. versus foreign, against $R_{c}$

(a) 5-8 years of education

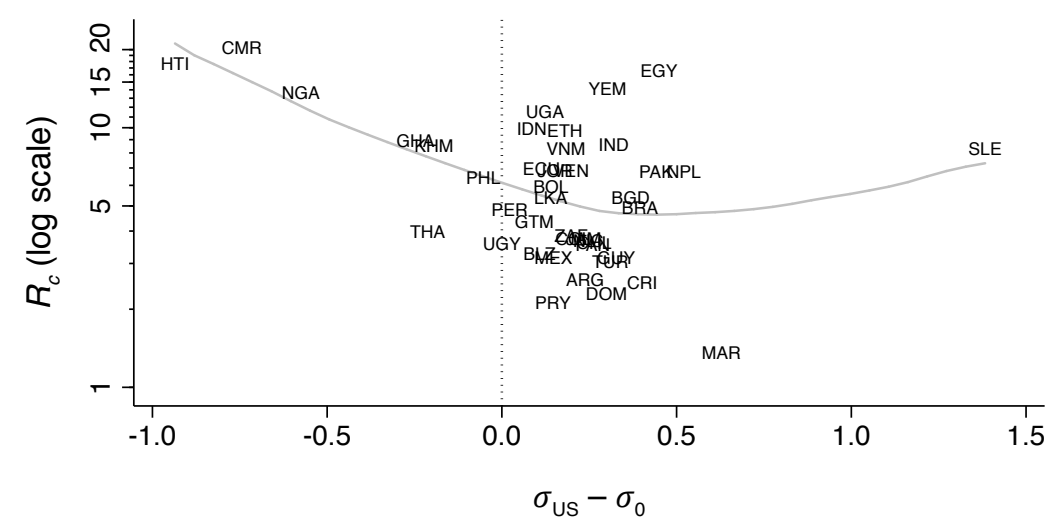

(b) 9-12 years of education

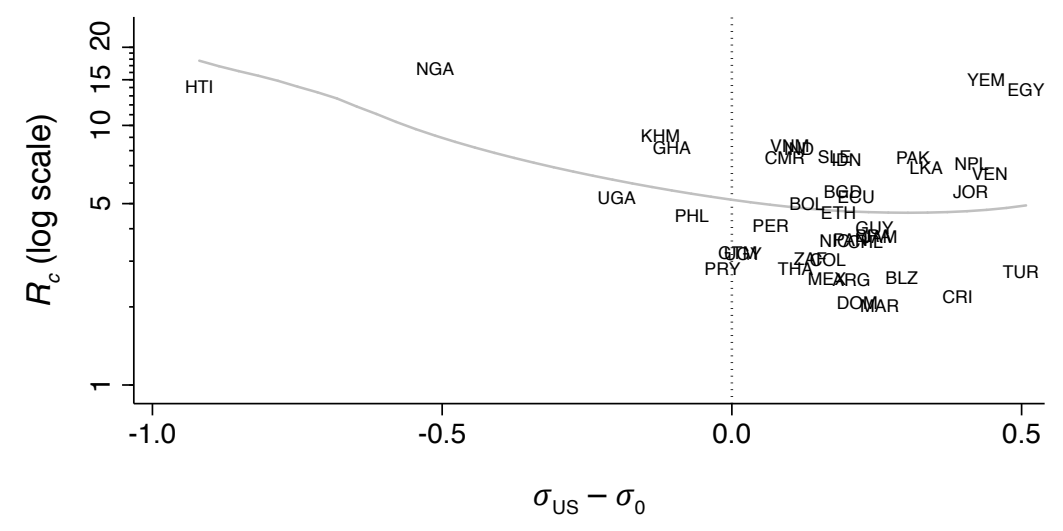

(c) $13+$ years of education

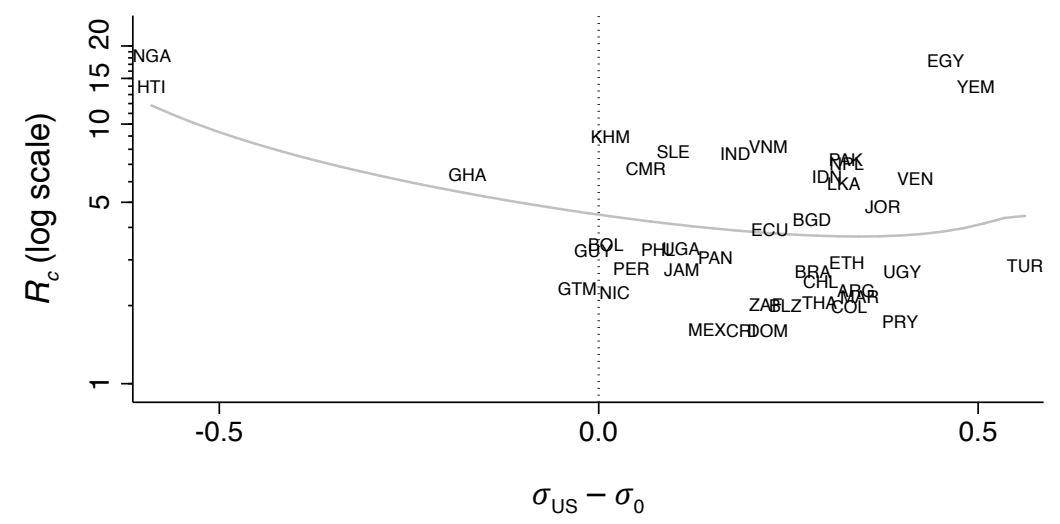

Gray line shows Fan local linear regression, Epanechnikov kernel, bandwidth 0.5. 
Figure 3: The degree of selection on observables against average wage at the origin, by observed skill

(a) 5-8 years of education

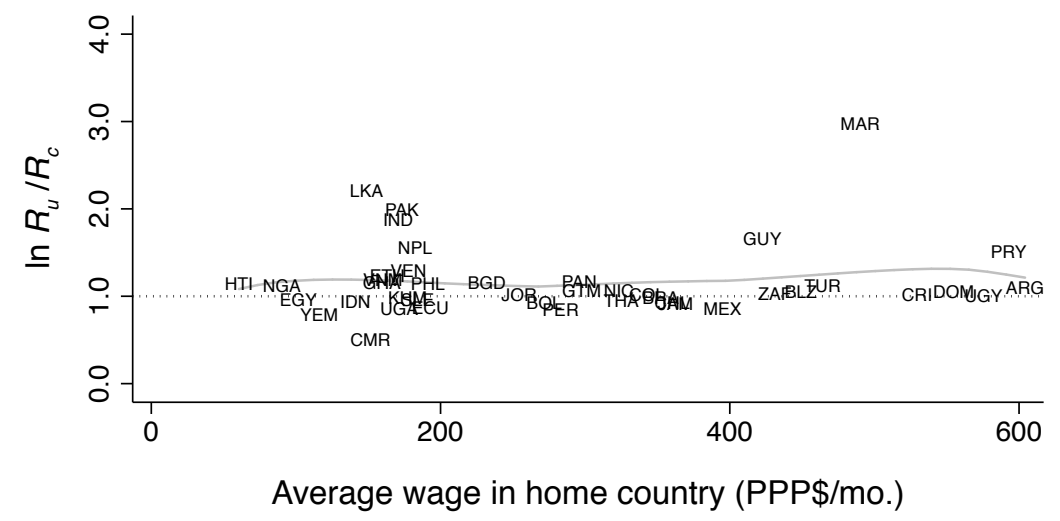

(b) 9-12 years of education

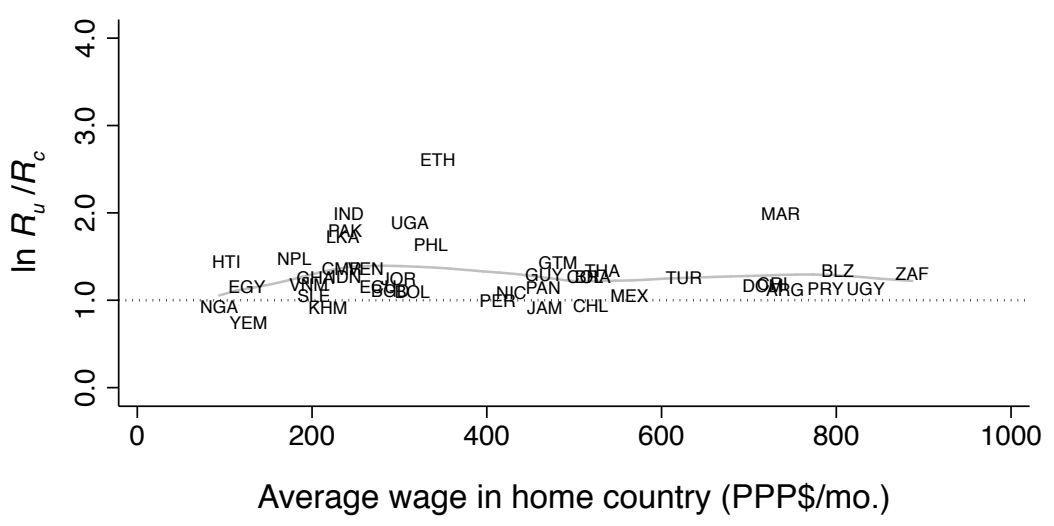

(c) $13+$ years of education

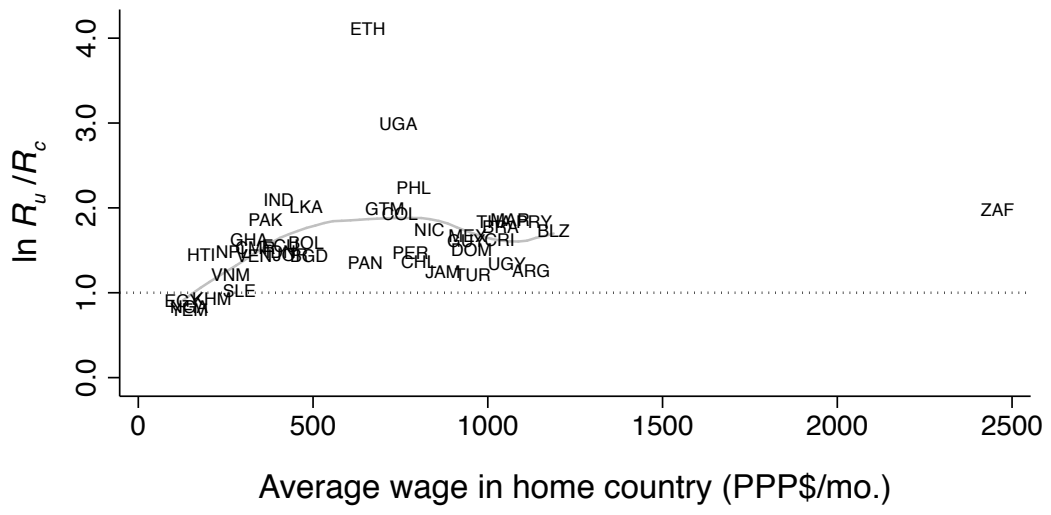

Gray line shows Fan local linear regression, Epanechnikov kernel, bandwidth 100 (panels a,b) or 175 (c). 
Table 6: Earnings of migrants relative to natives, by observed skill

\begin{tabular}{|c|c|c|c|c|c|c|}
\hline \multirow{3}{*}{$\begin{array}{l}\text { Years educ.: } \\
\text { South Africa }\end{array}$} & \multicolumn{6}{|c|}{$\ln \left(w_{\mathrm{US}}-w^{*}\right)$} \\
\hline & \multicolumn{2}{|c|}{$5-8$} & \multicolumn{2}{|c|}{ 9-12 } & \multicolumn{2}{|c|}{$13+$} \\
\hline & 1.200 & $(0.391)$ & 1.258 & $(0.131)$ & 1.622 & $(0.132)$ \\
\hline Uruguay & 1.500 & $(0.266)$ & 1.247 & $(0.163)$ & 0.994 & $(0.125)$ \\
\hline Paraguay & 0.906 & $(0.217)$ & 1.025 & $(0.179)$ & 0.712 & $(0.110)$ \\
\hline Belize & 1.068 & $(0.185)$ & 0.964 & $(0.115)$ & 0.753 & $(0.087)$ \\
\hline Cambodia & 1.090 & $(0.098)$ & .922 & $(0.071)$ & 0.825 & $(0.066)$ \\
\hline India & 1.066 & $(0.08$ & 915 & $(0.023)$ & .313 & $(0.025)$ \\
\hline Brazil & 1.248 & $(0.114)$ & 914 & $(0.038)$ & .910 & $(0.039)$ \\
\hline Argentina & 1.136 & $(0.13$ & 0.886 & $(0.07$ & 0.965 & $(0.082)$ \\
\hline Yemen & 1.186 & $(0.389)$ & .884 & $(0.196)$ & 0.653 & $(0.145)$ \\
\hline Guyana & 0.964 & $(0.075)$ & 0.870 & $(0.035)$ & 0.943 & $(0.044)$ \\
\hline Chile & 0.932 & $(0.127)$ & 0.862 & $(0.072)$ & 0.788 & $(0.070)$ \\
\hline Pakistan & 0.851 & $(0.119)$ & 0.831 & $(0.041)$ & 0.945 & $(0.039)$ \\
\hline Cameroon & 2.229 & $(0.338)$ & 0.819 & $(0.150)$ & 0.789 & $(0.086)$ \\
\hline Indonesia & .013 & $(0.201)$ & 0.813 & $(0.095)$ & 0.798 & $(0.078)$ \\
\hline Jamaica & .992 & $(0.056)$ & 0.810 & $(0.024)$ & 0.850 & $(0.026)$ \\
\hline Egypt & 1.210 & $(0.353)$ & 0.796 & $(0.067)$ & 0.814 & $(0.052)$ \\
\hline Turkey & 1.026 & $(0.127)$ & 0.792 & $(0.069)$ & 0.872 & $(0.065)$ \\
\hline Peru & 0.989 & $(0.076)$ & 0.790 & $(0.0$ & 0.698 & $(0.024)$ \\
\hline Venezuela & 0.876 & $(0.167)$ & 0.788 & $(0.065)$ & 0.775 & $(0.050)$ \\
\hline Panama & 0.755 & $(0.164)$ & 0.781 & $(0.066)$ & 0.811 & $(0.066)$ \\
\hline Ghana & 1.030 & $(0.163)$ & 0.774 & $(0.047)$ & 0.723 & $(0.046)$ \\
\hline Jordan & 1.248 & $(0.273)$ & 0.770 & $(0.090)$ & 0.696 & $(0.071)$ \\
\hline Vietnam & 0.961 & $(0.038)$ & 0.761 & $(0.018)$ & 0.787 & $(0.019)$ \\
\hline Uganda & 1.428 & $(0.598)$ & 0.757 & $(0.134)$ & 0.765 & $(0.107)$ \\
\hline Sri Lanka & 0.577 & $(0.181)$ & 0.745 & $(0.096)$ & 0.900 & $(0.109)$ \\
\hline Bangladesh & 0.895 & $(0.138)$ & 0.741 & $(0.060)$ & .679 & $(0.047)$ \\
\hline Bolivia & 1.174 & $(0.168)$ & 0.738 & $(0.071)$ & .642 & $(0.055)$ \\
\hline Costa Rica & 0.972 & $(0.113)$ & 0.738 & $(0.062)$ & .685 & $(0.053)$ \\
\hline Ethiopi & 1.148 & $(0.239)$ & 0.735 & $(0.050)$ & 0.611 & $(0.037)$ \\
\hline Colombia & 0.936 & $(0.047)$ & 0.730 & $(0.021)$ & 0.659 & $(0.020)$ \\
\hline Nicaragua & 0.866 & $(0.050)$ & 0.718 & $(0.029)$ & 0.617 & $(0.027)$ \\
\hline Nigeria & 0.889 & $(0.182)$ & 0.717 & $(0.043)$ & 0.835 & $(0.033)$ \\
\hline Guatemala & 0.929 & $(0.032)$ & 0.716 & $(0.018)$ & 0.588 & $(0.021)$ \\
\hline Sierra Leone & 1.100 & (1.068) & 0.708 & $(0.093)$ & 0.700 & $(0.077)$ \\
\hline Thailand & 0.943 & $(0.096)$ & 0.699 & $(0.054)$ & 0.689 & $(0.050)$ \\
\hline Philippines & 0.881 & $(0.034)$ & 0.696 & $(0.013)$ & 0.807 & $(0.013)$ \\
\hline Morocco & 0.481 & $(0.169)$ & 0.692 & $(0.067)$ & 0.753 & $(0.068)$ \\
\hline Dominican Rep & 0.920 & $(0.035)$ & 0.688 & $(0.018)$ & 0.575 & $(0.018)$ \\
\hline Ecuador & 0.979 & $(0.048)$ & 0.683 & $(0.029)$ & 0.580 & $(0.026)$ \\
\hline Mexico & 0.903 & $(0.018)$ & 0.672 & $(0.006)$ & 0.587 & (0.007) \\
\hline Haiti & 0.780 & $(0.038)$ & 0.670 & $(0.021)$ & 0.678 & $(0.023)$ \\
\hline Nepal & 0.892 & $(0.425)$ & 0.593 & $(0.120)$ & 0.593 & $(0.121)$ \\
\hline
\end{tabular}

Standard errors in parentheses. Sorted in descending order of the value for 912 years of education. 
Figure 4: Relative wage of observably equivalent U.S. and immigrant workers, versus $R_{c}$

(a) 5-8 years of education

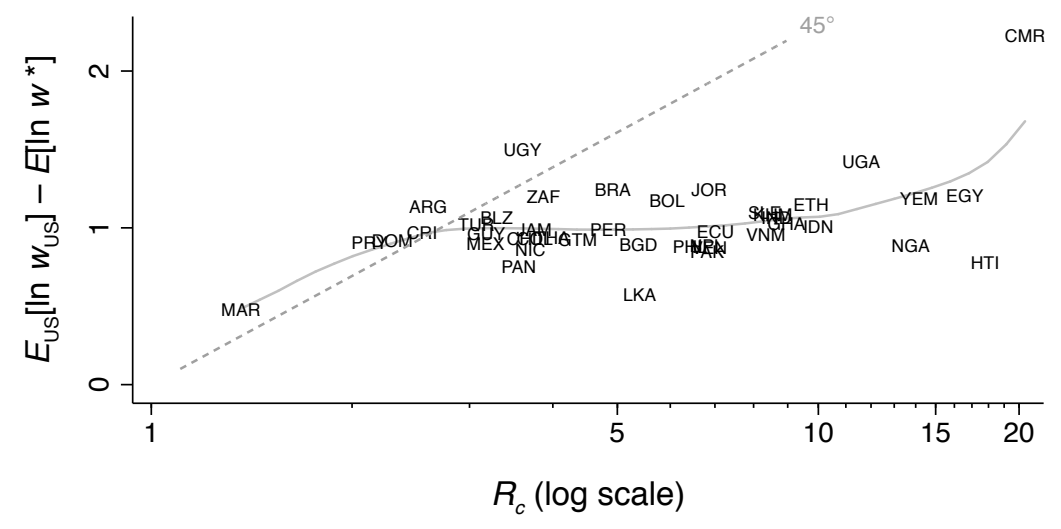

(b) 9-12 years of education

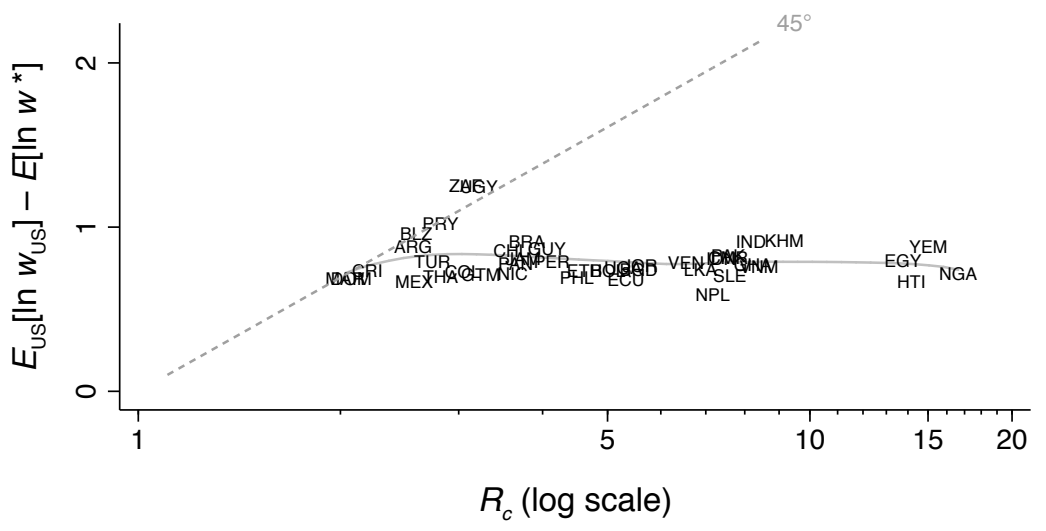

(c) 13+ years of education

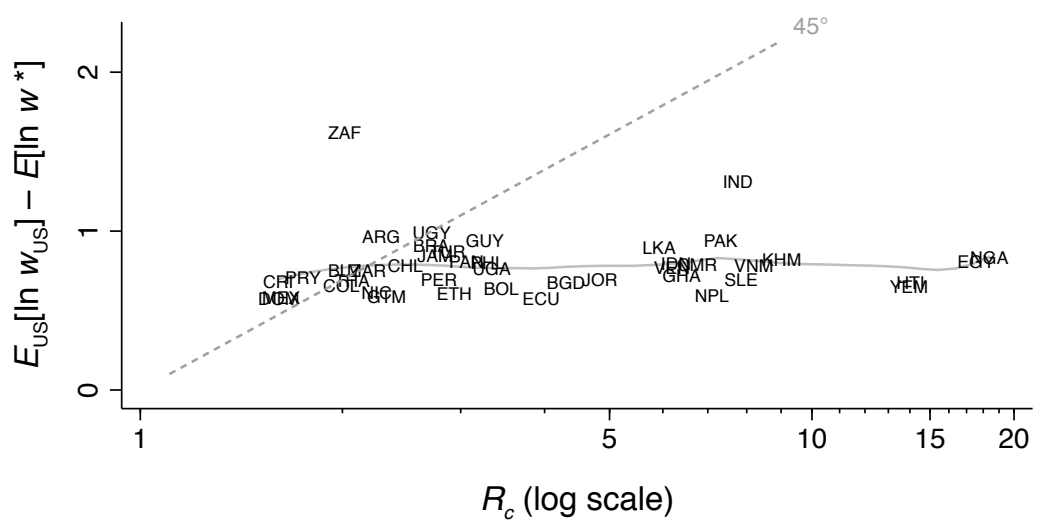

Gray line shows Fan local linear regression, Epanechnikov kernel, bandwidth 0.3 log points. 
Table 7: Reanalysis of Table 1 without the poor

\begin{tabular}{|c|c|c|c|c|}
\hline \multirow[b]{2}{*}{ Includes: } & \multicolumn{4}{|c|}{$R_{c}$} \\
\hline & All & $>\$ 1 /$ day & $>\$ 2 /$ day & $>\$ 4 /$ day \\
\hline Nigeria & 16.308 & 8.529 & 6.972 & 6.432 \\
\hline Yemen & 15.114 & 15.062 & 14.768 & 11.139 \\
\hline Haiti & 14.245 & 6.669 & 5.193 & 3.431 \\
\hline Egypt & 13.526 & 13.715 & 13.253 & 8.888 \\
\hline Cambodia & 9.139 & 8.544 & 8.212 & 7.238 \\
\hline Vietnam & 8.395 & 8.282 & 7.875 & 6.640 \\
\hline Ghana & 8.160 & 7.672 & 6.808 & 6.107 \\
\hline India & 7.859 & 7.683 & 7.261 & 5.981 \\
\hline Sierra Leone & 7.608 & 6.882 & 6.823 & 6.254 \\
\hline Cameroon & 7.477 & 7.424 & 7.096 & 6.208 \\
\hline Pakistan & 7.433 & 7.573 & 7.571 & 7.131 \\
\hline Indonesia & 7.069 & 6.877 & 6.726 & 6.138 \\
\hline Nepal & 6.692 & 6.672 & 6.670 & 4.913 \\
\hline Sri Lanka & 6.657 & 6.507 & 6.243 & 5.753 \\
\hline Venezuela & 6.532 & 6.527 & 6.495 & 6.194 \\
\hline Jordan & 5.593 & 5.528 & 5.502 & 5.337 \\
\hline Bangladesh & 5.487 & 5.749 & 5.519 & 5.082 \\
\hline Ecuador & 5.368 & 5.273 & 5.143 & 4.726 \\
\hline Uganda & 5.286 & 4.876 & 4.824 & 4.533 \\
\hline Bolivia & 5.106 & 4.941 & 4.765 & 4.494 \\
\hline Ethiopia & 4.585 & 4.523 & 4.512 & 4.272 \\
\hline Philippines & 4.504 & 4.402 & 4.232 & 3.846 \\
\hline Peru & 4.153 & 4.140 & 3.977 & 3.673 \\
\hline Guyana & 4.067 & 4.056 & 4.059 & 4.043 \\
\hline Jamaica & 3.790 & 3.919 & 4.074 & 3.647 \\
\hline Brazil & 3.769 & 3.799 & 3.850 & 3.880 \\
\hline Nicaragua & 3.643 & 3.677 & 3.649 & 3.616 \\
\hline Panama & 3.635 & 3.613 & 3.519 & 3.390 \\
\hline Chile & 3.582 & 3.580 & 3.563 & 3.513 \\
\hline Guatemala & 3.226 & 3.083 & 3.059 & 2.961 \\
\hline Uruguay & 3.181 & 3.183 & 3.213 & 3.259 \\
\hline Colombia & 3.068 & 3.032 & 2.973 & 2.953 \\
\hline South Africa & 2.985 & 3.009 & 3.007 & 2.881 \\
\hline Paraguay & 2.907 & 2.918 & 2.918 & 2.859 \\
\hline Thailand & 2.828 & 2.865 & 2.876 & 2.706 \\
\hline Turkey & 2.735 & 2.740 & 2.736 & 2.725 \\
\hline Belize & 2.633 & 2.754 & 2.874 & 2.914 \\
\hline Mexico & 2.589 & 2.540 & 2.498 & 2.456 \\
\hline Argentina & 2.486 & 2.480 & 2.475 & 2.474 \\
\hline Costa Rica & 2.194 & 2.189 & 2.201 & 2.172 \\
\hline Dominican Rep & 2.084 & 2.079 & 2.080 & 2.042 \\
\hline Morocco & 2.026 & 1.937 & 1.975 & 1.940 \\
\hline
\end{tabular}

Sorted in descending order of the original $R_{c}$ in Table 1. Estimates are for 35-39 year-old males, 9-12 years education acquired in home country. 
Table 8: Wage differences for observably equivalent workers without policy restrictions, purchasing power parity

\begin{tabular}{|c|c|c|c|c|c|c|}
\hline \multirow[b]{2}{*}{$\begin{array}{l}\text { Puerto Rico } \\
\text {. . ethnic Puerto Rican }\end{array}$} & \multicolumn{2}{|c|}{ No controls } & \multicolumn{4}{|c|}{ Controls } \\
\hline & $\begin{array}{c}\ln \hat{R}_{u} \\
0.353 \\
0.353\end{array}$ & $\begin{array}{c}\text { s.e. } \\
(0.006) \\
(0.007)\end{array}$ & $\begin{array}{l}\ln \hat{R}_{c} \\
0.448 \\
0.445\end{array}$ & $\begin{array}{c}\text { s.e. } \\
(0.018) \\
(0.019)\end{array}$ & $\begin{array}{c}\hat{R}_{c} \\
1.565 \\
1.560\end{array}$ & $\begin{array}{c}\text { s.e. } \\
(0.025) \\
(0.026)\end{array}$ \\
\hline $\begin{array}{l}\text { Guam } \\
\text {...ethnic Guamanian }\end{array}$ & $\begin{array}{l}0.336 \\
0.313\end{array}$ & $\begin{array}{l}(0.027) \\
(0.039)\end{array}$ & $\begin{array}{l}0.431 \\
0.269\end{array}$ & $\begin{array}{l}(0.065) \\
(0.098)\end{array}$ & $\begin{array}{l}1.538 \\
1.309\end{array}$ & $\begin{array}{l}(0.044) \\
(0.041)\end{array}$ \\
\hline
\end{tabular}

Estimates with controls are for 35-39 year-old males with 9-12 years of education. Standard errors in parentheses (robust for $\ln \hat{R}_{u}$ and $\ln \hat{R}_{c}$, bootstrapped for $\hat{R}_{c}$ ). Sample sizes are as follows: PR born: 30,900 on mainland, 47,085 in Puerto Rico. PR born and ethnically Puerto Rican: 27,906 on mainland, 46,640 in Puerto Rico. Guam born: 1,923 on mainland, 2,406 in Guam. Guam born and ethnically Guamanian: 667 on mainland, 1,262 in Guam.

Figure 5: Upper envelope of wages-forgone curve $\left(\bar{w}_{0}\right)$ by working-age population

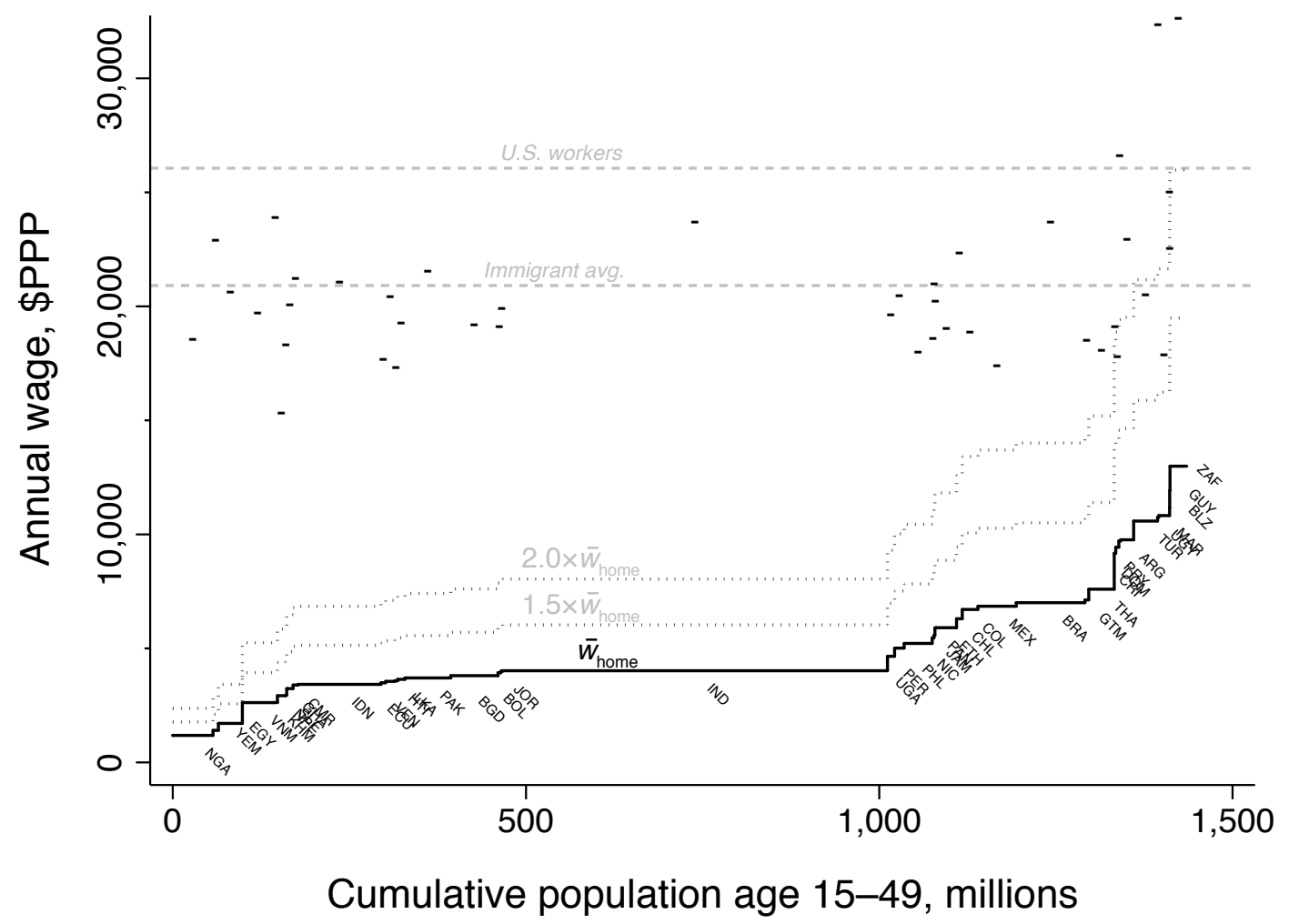

For 35-39 year-old male workers with 9-12 years of schooling acquired in the home country. Upper envelope of wages forgone $\left(\bar{w}_{0}\right)$ estimated using lower bounds on $R$ from Table 3 col. $2: \bar{w}_{0}=w_{\mathrm{US}} /\left.R\right|_{\delta=1, \Pi=1.3}$. Single dash is wage if immigrant in U.S., born and educated in each country specified directly below that dash. "Immigrant avg." is unweighted mean across country-of-birth for immigrants in U.S. "U.S. workers" is mean for U.S. born. 


\section{Online Appendix "Bounding the Price Equivalent of Migration Barriers"}

\section{A1 Sources}

Survey data on wages and other worker characteristics from 42 developing countries were compiled by Indermit S. Gill and his team at the World Bank. Table A1 lists the original sources and size of each sample, as well as reproducing the exact text of the wage question from each survey. A detailed description of the database can be found in Montenegro and Hirn (2009).

In three surveys (India, Turkey and the US), the respondent's education level is listed as achievement categories rather than as years of schooling. We translate these categories into years of schooling according to the information available in the surveys. In the particular case of the US we use the following concordance: 0 years if "less than 1st grade"; 3 years if "1st through 4th grade"; 5.6666 years if " 5 th or 6th"; 7.6666 years if "7th or 8th"; $9,10,11$, or 12 have separate categories; 12 years if "high school equivalent"; 13.5 years if "some college but no degree"; 14 years if "associate degree" or equivalent; 16 years if "bachelor's degree"; 18 years if "master's degree"; 19 years if "professional degree"; 20 years if "doctoral degree". This is a compromise blend of the methods used in Bratsberg and Terrell (2002) and in Jaeger (1997).

All data except the cost of living index used in the wage regressions for Puerto Rico come from the United States Public Use Microdata Sample (5\%) of the 2000 census. The Puerto Rico cost of living index comes from the revised 2004 version of the Berry-Fording-Hanson (BFH) state cost of living index (described in Berry et al. 2000), which excludes Alaska, Hawaii, and the District of Columbia. In the BFH index for 1999, 1 is the purchasing power of $\$ 1$ in the median US state. For Puerto Rico we use 0.86, which is the PPP conversion factor for 1999 from the Penn World Table 6.2 (Heston et al. 2006).

\section{A2 Quality}

An important question we do not take up in the text is the degree to which the surveys are representative of the wage sector and of the country - though all were designed to be. One way to check the representativeness of the wage surveys is to compare national accounts estimates of labor income per worker at PPP in each country to the average wage from the surveys we use. There is no reason to expect these to be equal - most importantly because the wage data we use do not include self-employed people and therefore do not include large portions of the informal sector, and even informal-sector wage workers can be harder to sample than formal-sector workers. But enormous differences between the two could signal problems in the representativeness of the survey data.

Figure A1 plots this comparison. Labor income per worker is calculated by the method of Gollin (2002), under the assumption that a 0.65 share of GDP accrues to labor. The dotted line shows a 45-degree line and the solid line shows a cubic least-squares fit to the data including a dummy for Honduras $\left(R^{2}=0.756\right.$; or $R^{2}=0.607$ without the Honduras dummy). Large amounts of self-employment would tend to push countries down and to the right; large amounts of low-wage informal sector work would tend to push countries up and to the left.

We draw three lessons from Figure A1. First, the agreement is in general very good. Average wage is typically some reasonable fraction of average labor income, varying across countries as would be expected given different relative sizes of the informal sector and the self-employed sector. Second, 
Figure A1: Comparison of labor income per worker and survey-based wages

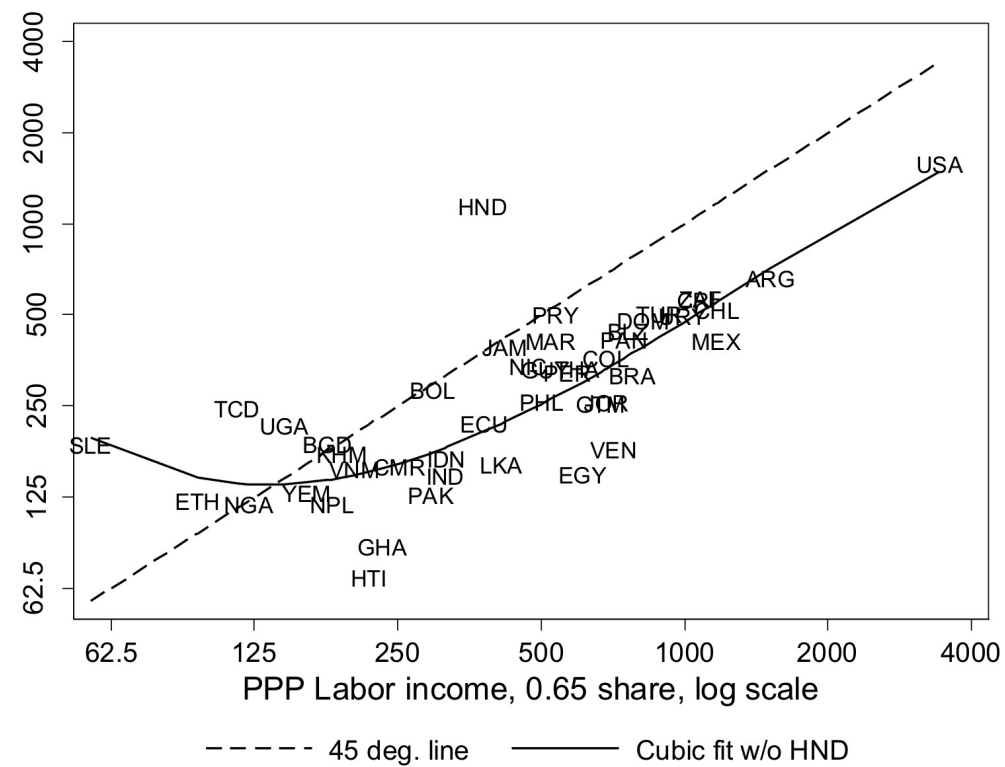

Line shows cubic regression fit of $\ln$ (wage) on $\ln$ (labor income), its square, and its cube, with a dummy for Honduras.

formal-sector wages are clearly not representative of typical worker earnings in the poorest countries with very large informal sectors (e.g. Sierra Leone, Chad, Nigeria, Bangladesh, Ethiopia, Uganda). This is to be expected given that earnings gaps between the formal and informal sector are highest in the poorest countries (Vollrath 2009). Third, the Honduras survey appears anomalous and we drop Honduras from subsequent reported analysis (since our preferred results are from bi-lateral regressions this has no consequence for other countries' results). Overall, this analysis highlights the fact that all of the estimates to follow can only be interpreted as applying to a worker moving across the formal wage-labor sector. If indeed the formal-informal gap is much larger in poor countries, this underestimates the wage gains for a typical worker.

Appendix Table A1: Household survey data sources

\begin{tabular}{lcllcl} 
Country & Year & Survey & Survey agency & Sample & Wage question \\
\hline Argentina & 2001 & $\begin{array}{l}\text { Encuesta Perma- } \\
\text { nente de Hogares }\end{array}$ & $\begin{array}{l}\text { Instituto Nacional } \\
\text { de Estadísticas } \\
\text { Censos (INDEC) }\end{array}$ & 19,706 & $\begin{array}{l}\text { Cuanto cobró por ese mes por } \\
\text { esos conceptos? (Monto total de } \\
\text { sueldos/jornales, salario familiar, } \\
\text { horas extras, otras bonificaciones } \\
\text { habituales y tickets vales o simi- } \\
\text { lares) }\end{array}$ \\
\hline Bangladesh & 2000 & $\begin{array}{l}\text { Household In- } \\
\text { come Expendi- } \\
\text { ture Survey }\end{array}$ & Bureau of Statistics & 3,517 & $\begin{array}{l}\text { What is your total net take-home } \\
\text { monthly cash remuneration after } \\
\text { all deductions at source? }\end{array}$ \\
\hline Belize & 1995 & $\begin{array}{l}\text { Survey of Living } \\
\text { Conditions }\end{array}$ & $\begin{array}{l}\text { Central Statistical } \\
\text { Office }\end{array}$ & 783 & $\begin{array}{l}\text { What is your gross monthly in- } \\
\text { come? }\end{array}$ \\
\hline Bolivia & 2002 & $\begin{array}{l}\text { Encuesta de } \\
\text { Hogares }\end{array}$ & $\begin{array}{l}\text { Instituto Nacional } \\
\text { de Estadísticas }\end{array}$ & 3,244 & $\begin{array}{l}\text { Cuál es el salario líquido de su } \\
\text { trabajo en horario normal? }\end{array}$ \\
\hline
\end{tabular}




\begin{tabular}{|c|c|c|c|c|c|}
\hline Brazil & 2005 & $\begin{array}{l}\text { Pesquisa Na- } \\
\text { cional per } \\
\text { Amostra de } \\
\text { Domicílios }\end{array}$ & $\begin{array}{l}\text { Instituto Brasileiro } \\
\text { de Geografia e Es- } \\
\text { tatística }\end{array}$ & 107,955 & $\begin{array}{l}\text { Qual era o rendimento mensual } \\
\text { que você ganhava normalmente } \\
\text { em setembro de } 2003 \text {, nesse tra- } \\
\text { balho? }\end{array}$ \\
\hline Cambodia & 2004 & $\begin{array}{l}\text { Household Socio- } \\
\text { Economic Sur- } \\
\text { vey }\end{array}$ & $\begin{array}{l}\text { National Institute of } \\
\text { Statistics }\end{array}$ & 8,578 & $\begin{array}{l}\text { How much did you earn in } \\
\text { salary/wages from this activity } \\
\text { last month? }\end{array}$ \\
\hline Cameroon & 2001 & $\begin{array}{l}\text { Enquête Camer- } \\
\text { ounaise Auprès } \\
\text { de Ménages }\end{array}$ & $\begin{array}{l}\text { Direction de la } \\
\text { Statistique et de } \\
\text { la Comptabilité } \\
\text { Nationale }\end{array}$ & 5,098 & $\begin{array}{l}\text { A quel montant estimez vous } \\
\text { la totalité des revenues issus de } \\
\text { votre emploi principal le mois } \\
\text { dernier? }\end{array}$ \\
\hline Chile & 2003 & $\begin{array}{l}\text { Encuesta de } \\
\text { Caracterización } \\
\text { Socio-económica } \\
\text { Nacional }\end{array}$ & $\begin{array}{l}\text { Ministerio de Plani- } \\
\text { ficación }\end{array}$ & 59,532 & $\begin{array}{l}\text { En el mes pasado, cuál fue su } \\
\text { ingreso o remuneración líquida en } \\
\text { su ocupación principal? }\end{array}$ \\
\hline Colombia & 2000 & $\begin{array}{l}\text { Encuesta Con- } \\
\text { tinua de Hogares }\end{array}$ & $\begin{array}{l}\text { Departamento Ad- } \\
\text { ministrativo Na- } \\
\text { cional de Estadís- } \\
\text { tica }\end{array}$ & 27,996 & $\begin{array}{l}\text { Cuanto ganó el mes pasado en } \\
\text { este empleo? (incluya propinas y } \\
\text { comisiones y excluya viáticos y } \\
\text { pagos en especie) }\end{array}$ \\
\hline $\begin{array}{l}\text { Costa } \\
\text { Rica }\end{array}$ & 2001 & $\begin{array}{l}\text { Encuesta de } \\
\text { Hogares de } \\
\text { Propósitos Mul- } \\
\text { tiples }\end{array}$ & $\begin{array}{l}\text { Instituto Nacional } \\
\text { de Estadísticas y } \\
\text { Censos }\end{array}$ & 12,503 & $\begin{array}{l}\text { En su ocupación principal, cuál } \\
\text { fue el ingreso efectivamente } \\
\text { percibido por concepto de sueldo, } \\
\text { salario, jornal, propinas, horas ex- } \\
\text { tras, en el último periodo de pago } \\
\text { (semana, quincena o mes)? }\end{array}$ \\
\hline $\begin{array}{l}\text { Dominican } \\
\text { Republic }\end{array}$ & 1997 & $\begin{array}{l}\text { Encuesta Na- } \\
\text { cional de Fuerza } \\
\text { de Trabajo }\end{array}$ & $\begin{array}{l}\text { Departamento de } \\
\text { Cuentas Nacionales } \\
\text { y Estadísticas } \\
\text { Económicas del } \\
\text { Banco Central } \\
\end{array}$ & 3,056 & $\begin{array}{l}\text { Cuánto le pagan o gana usted y } \\
\text { cada qué tiempo en ese trabajo? }\end{array}$ \\
\hline Ecuador & 2004 & $\begin{array}{l}\text { Encuesta de Em- } \\
\text { pleo, Desempleo } \\
\text { y Subempleo }\end{array}$ & $\begin{array}{l}\text { Instituto Nacional } \\
\text { de Estadísticas y } \\
\text { Censos }\end{array}$ & 17,576 & $\begin{array}{l}\text { En su ocupación cuánto dinero } \\
\text { líquido recibió por concepto de } \\
\text { sueldo o salario u otros ingresos } \\
\text { en el mes de marzo? }\end{array}$ \\
\hline Egypt & 1998 & $\begin{array}{l}\text { Labor Market } \\
\text { Survey }\end{array}$ & $\begin{array}{l}\text { Central Agency for } \\
\text { Public Mobilization } \\
\text { and Statistics }\end{array}$ & 4,776 & $\begin{array}{l}\text { What is the net amount received } \\
\text { in basic net wage? }\end{array}$ \\
\hline Ethiopia & 2005 & $\begin{array}{l}\text { National Labour } \\
\text { Force }\end{array}$ & $\begin{array}{l}\text { Central Statistical } \\
\text { Authority }\end{array}$ & 22,568 & $\begin{array}{l}\text { What was the amount paid in } \\
\text { your main occupation during the } \\
\text { last period? }\end{array}$ \\
\hline Ghana & 1991 & $\begin{array}{l}\text { Living Standards } \\
\text { Surveys Round } \\
\text { Three }\end{array}$ & Statistical Office & 5,749 & $\begin{array}{l}\text { What is the amount of money } \\
\text { you will receive for this work? }\end{array}$ \\
\hline Guatemala & 2002 & $\begin{array}{l}\text { Encuesta Na- } \\
\text { cional Sobre } \\
\text { Condiciones de } \\
\text { Vida }\end{array}$ & $\begin{array}{l}\text { Instituto Nacional } \\
\text { de Estadísticas }\end{array}$ & 2,584 & $\begin{array}{l}\text { Cuál es el último ingreso neto o } \\
\text { ganancia que recibió? }\end{array}$ \\
\hline Guyana & 1992 & $\begin{array}{l}\text { Living Standards } \\
\text { Measurement } \\
\text { Survey }\end{array}$ & Bureau of Statistics & 1,266 & $\begin{array}{l}\text { What is your cash income from } \\
\text { paid employment (BASIC wage } \\
\text { or salary)? }\end{array}$ \\
\hline Haiti & 2001 & $\begin{array}{l}\text { Les Conditions } \\
\text { de Vie en Haïti }\end{array}$ & $\begin{array}{l}\text { Institut Haïtien } \\
\text { de Statistique et } \\
\text { d'Informatique }\end{array}$ & 1,220 & $\begin{array}{l}\text { What is your wage, salary, com- } \\
\text { mission payments, bonuses or } \\
\text { other cash income (includying } \\
\text { overtime) from employer? }\end{array}$ \\
\hline India & 1999 & $\begin{array}{l}\text { Socio-economic } \\
\text { Survey }\end{array}$ & $\begin{array}{l}\text { National Sample } \\
\text { Survey Organization }\end{array}$ & 94,306 & $\begin{array}{l}\text { What are the wage and salary } \\
\text { earnings (received or receivable) } \\
\text { for the work done during the } \\
\text { week? }\end{array}$ \\
\hline Indonesia & 2002 & $\begin{array}{l}\text { Survei Sosial } \\
\text { Ekonomi Na- } \\
\text { sional }\end{array}$ & $\begin{array}{l}\text { Badan Pusat Statis- } \\
\text { tik }\end{array}$ & 129,279 & $\begin{array}{l}\text { How much is the wage/net salary } \\
\text { received in a month of main } \\
\text { work? }\end{array}$ \\
\hline Jamaica & 2002 & $\begin{array}{l}\text { Jamaica Sur- } \\
\text { vey of Living } \\
\text { Conditions }\end{array}$ & $\begin{array}{l}\text { Statistical Institute } \\
\text { of Jamaica }\end{array}$ & 3,723 & $\begin{array}{l}\text { What is the value of all income } \\
\text { received in cash or in kind during } \\
\text { the past } 12 \text { months? }\end{array}$ \\
\hline Jordan & 2002 & $\begin{array}{l}\text { Household In- } \\
\text { come Expendi- } \\
\text { ture Survey }\end{array}$ & $\begin{array}{l}\text { Household Surveys } \\
\text { Directorate }\end{array}$ & 12,824 & $\begin{array}{l}\text { What is the total income from } \\
\text { employment? }\end{array}$ \\
\hline Mexico & 2002 & $\begin{array}{l}\text { Encuesta Na- } \\
\text { cional de Ingre- } \\
\text { sos y Gastos de } \\
\text { los Hogares }\end{array}$ & $\begin{array}{l}\text { Instituto Nacional } \\
\text { de Estadística, Ge- } \\
\text { ografía e Infor- } \\
\text { mática }\end{array}$ & 18,064 & $\begin{array}{l}\text { Cuánto recibió el mes pasado por } \\
\text { sueldos, salarios y jornales en el } \\
\text { mes pasado? (declare su ingreso } \\
\text { bruto) }\end{array}$ \\
\hline
\end{tabular}




\begin{tabular}{|c|c|c|c|c|c|}
\hline Morocco & 1998 & $\begin{array}{l}\text { Enquête Na- } \\
\text { tionale sur les } \\
\text { Niveaux de Vie } \\
\text { des Ménages }\end{array}$ & $\begin{array}{l}\text { Secretariat d'État } \\
\text { à la Population, } \\
\text { Direction de la } \\
\text { Statistique }\end{array}$ & 4,043 & $\begin{array}{l}\text { Quel a été votre salaire en espèce } \\
\text { dans votre travail? }\end{array}$ \\
\hline Nepal & 2003 & $\begin{array}{l}\text { Living Standards } \\
\text { Survey II }\end{array}$ & $\begin{array}{l}\text { Central Bureau of } \\
\text { Statistics }\end{array}$ & 2,216 & $\begin{array}{l}\text { How much did you get in cash } \\
\text { per day for this job? }\end{array}$ \\
\hline Nicaragua & 2001 & $\begin{array}{l}\text { Encuesta Na- } \\
\text { cional de Hoga- } \\
\text { res Sobre Medi- } \\
\text { ción de Nivel de } \\
\text { Vida }\end{array}$ & $\begin{array}{l}\text { Instituto Nacional } \\
\text { de Estadísticas y } \\
\text { Censos }\end{array}$ & 3,757 & $\begin{array}{l}\text { Cuál es el último ingreso neto que } \\
\text { tuvo usted? }\end{array}$ \\
\hline Nigeria & 2003 & $\begin{array}{l}\text { Living Standards } \\
\text { Surveys }\end{array}$ & $\begin{array}{l}\text { Federal Office of } \\
\text { Statistics }\end{array}$ & 3,084 & $\begin{array}{l}\text { What is the amount of money } \\
\text { you received or you will receive } \\
\text { for this work? }\end{array}$ \\
\hline Pakistan & 2001 & $\begin{array}{l}\text { Integrated } \\
\text { Household Sur- } \\
\text { vey }\end{array}$ & $\begin{array}{l}\text { Federal Bureau of } \\
\text { Statistics }\end{array}$ & 13,186 & $\begin{array}{l}\text { How much is your take-home } \\
\text { pay, including bonuses or cash } \\
\text { allowances? }\end{array}$ \\
\hline Panama & 2003 & $\begin{array}{l}\text { Encuesta de } \\
\text { Hogares }\end{array}$ & $\begin{array}{l}\text { Dirección de Es- } \\
\text { tadística y Censo }\end{array}$ & 14,392 & $\begin{array}{l}\text { Cuál es salario o ingreso mensual } \\
\text { en su trabajo? (si es empleado } \\
\text { investigue sueldos y salarios } \\
\text { brutos sin deducir impuestos } \\
\text { ni contribuciones al seguro social) }\end{array}$ \\
\hline Paraguay & 2001 & $\begin{array}{l}\text { Encuesta Perma- } \\
\text { nente de Hogares }\end{array}$ & $\begin{array}{l}\text { Dirección General } \\
\text { de Estadísticas, } \\
\text { Encuestas y Censos }\end{array}$ & 6,254 & $\begin{array}{l}\text { Cuál fue el monto del último pago } \\
\text { neto o líquido que recibió (in- } \\
\text { cluyen descuentos por préstamos, } \\
\text { asociaciones, etc.)? Si no le han } \\
\text { pagado todavía, cuánto espera } \\
\text { que le paguen y que periodo de } \\
\text { tiempo incluye este pago? }\end{array}$ \\
\hline Peru & 2002 & $\begin{array}{l}\text { Encuesta } \mathrm{Na-} \\
\text { cional de Hoga- } \\
\text { res }\end{array}$ & $\begin{array}{l}\text { Instituto Nacional } \\
\text { de Estadísticas e } \\
\text { Informática }\end{array}$ & 13,367 & $\begin{array}{l}\text { Cuál fue ingreso total en el pago } \\
\text { anterior incluyendo horas extras, } \\
\text { bonificaciones, pago por concepto } \\
\text { de refrigerio, mobilidad, comi- } \\
\text { siones, etc.? }\end{array}$ \\
\hline Philippines & 2002 & $\begin{array}{l}\text { Annual Poverty } \\
\text { Indicators Sur- } \\
\text { vey }\end{array}$ & $\begin{array}{l}\text { National Statistics } \\
\text { Office }\end{array}$ & 34,626 & $\begin{array}{l}\text { Total Income, salary/wages from } \\
\text { employment }\end{array}$ \\
\hline $\begin{array}{l}\text { Sierra } \\
\text { Leone }\end{array}$ & 2003 & $\begin{array}{l}\text { Integrated } \\
\text { Household Sur- } \\
\text { vey }\end{array}$ & $\begin{array}{l}\text { Statistics Sierra } \\
\text { Leone }\end{array}$ & 565 & $\begin{array}{l}\text { What is the amount of money } \\
\text { you received or you will receive? }\end{array}$ \\
\hline $\begin{array}{l}\text { South } \\
\text { Africa }\end{array}$ & 2000 & $\begin{array}{l}\text { Labour Force } \\
\text { Survey }\end{array}$ & $\begin{array}{l}\text { Statistics South } \\
\text { Africa }\end{array}$ & 21,707 & $\begin{array}{l}\text { What is your total salary/pay in } \\
\text { your main job? }\end{array}$ \\
\hline $\begin{array}{l}\text { Sri } \\
\text { Lanka }\end{array}$ & 2002 & $\begin{array}{l}\text { Household In- } \\
\text { come and Ex- } \\
\text { penditure Survey }\end{array}$ & $\begin{array}{l}\text { Department of Cen- } \\
\text { sus and Statistics }\end{array}$ & 16,772 & $\begin{array}{l}\text { What is the wage/salary you } \\
\text { received last calendar month? }\end{array}$ \\
\hline Thailand & 2002 & $\begin{array}{l}\text { Socio-economic } \\
\text { Survey }\end{array}$ & $\begin{array}{l}\text { National Statistical } \\
\text { Office }\end{array}$ & 28,258 & Wage and salaries \\
\hline Turkey & 2005 & $\begin{array}{l}\text { Household } \\
\text { Labour Force } \\
\text { Survey }\end{array}$ & $\begin{array}{l}\text { State Institute of } \\
\text { Statistics }\end{array}$ & 75,610 & $\begin{array}{l}\text { How much did you earn from } \\
\text { main job activity during the last } \\
\text { month? }\end{array}$ \\
\hline Uganda & 2002 & $\begin{array}{l}\text { Socio-economic } \\
\text { Survey }\end{array}$ & $\begin{array}{l}\text { Uganda Bureau of } \\
\text { Statistics }\end{array}$ & 3,204 & $\begin{array}{l}\text { How much do you earn per pe- } \\
\text { riod? (effort should be taken to } \\
\text { get the net salary after the deduc- } \\
\text { tion of taxes) }\end{array}$ \\
\hline $\begin{array}{l}\text { United } \\
\text { States }\end{array}$ & 1999 & $\begin{array}{l}2000 \text { Census } \\
\text { Population and } \\
\text { Housing (Public } \\
\text { Use Microdata } \\
\text { Sample) }\end{array}$ & US Census Bureau & $1,124,253$ & $\begin{array}{l}\text { Wages, salary, commissions, } \\
\text { bonuses, or tips from all jobs. } \\
\text { Report amount before deductions } \\
\text { for taxes, bonds, dues or other } \\
\text { items }\end{array}$ \\
\hline Uruguay & 1995 & $\begin{array}{l}\text { Encuesta Con- } \\
\text { tinua de Hogares }\end{array}$ & $\begin{array}{l}\text { Instituto Nacional } \\
\text { de Estadísticas }\end{array}$ & 19,142 & $\begin{array}{l}\text { Cuánto ganó el mes pasado como } \\
\text { empleado u obrero del sector } \\
\text { público o privado? }\end{array}$ \\
\hline Venezuela & 2004 & $\begin{array}{l}\text { Encuesta de } \\
\text { Hogares por } \\
\text { Muestreo Na- } \\
\text { cional }\end{array}$ & $\begin{array}{l}\text { Instituto Nacional } \\
\text { de Estadísticas }\end{array}$ & 34,569 & $\begin{array}{l}\text { En un mes normal cuánto es su } \\
\text { ganancia neta? }\end{array}$ \\
\hline Vietnam & 2002 & $\begin{array}{l}\text { Household Liv- } \\
\text { ing Standard } \\
\text { Survey }\end{array}$ & $\begin{array}{l}\text { General Statistical } \\
\text { Office }\end{array}$ & 19,920 & $\begin{array}{l}\text { In the past } 12 \text { months, how much } \\
\text { did you receive from this work in } \\
\text { money and in kind? }\end{array}$ \\
\hline Yemen & 2005 & $\begin{array}{l}\text { Household Bud- } \\
\text { get Survey }\end{array}$ & $\begin{array}{l}\text { Central Statistical } \\
\text { Organization }\end{array}$ & 10,583 & $\begin{array}{l}\text { How much was your last pay? } \\
\text { (net of taxes and any other de- } \\
\text { duction) }\end{array}$ \\
\hline
\end{tabular}

